\title{
How stratospheric are deep stratospheric intrusions?
}

\author{
T. Trickl ${ }^{1}$, H. Vogelmann ${ }^{1}$, H. Giehl ${ }^{1}$, H.-E. Scheel ${ }^{1, \dagger}$, M. Sprenger ${ }^{2}$, and A. Stohl ${ }^{3}$ \\ ${ }^{1}$ Karlsruher Institut für Technologie, Institut für Meteorologie und Klimaforschung (IMK-IFU), \\ Kreuzeckbahnstr. 19, 82467 Garmisch-Partenkirchen, Germany \\ ${ }^{2}$ Eidgenössische Technische Hochschule (ETH) Zürich, Institut für Atmosphäre und Klima, \\ Universitätstraße 16, 8092 Zürich, Switzerland \\ ${ }^{3}$ Norwegian Institute for Air Research, P.O. Box 100, Instituttveien 18, 2027 Kjeller, Norway \\ $\dagger$ deceased, 23 June 2013
}

Correspondence to: T. Trickl (thomas.trickl@kit.edu)

Received: 11 February 2014 - Published in Atmos. Chem. Phys. Discuss.: 12 June 2014

Revised: 11 August 2014 - Accepted: 26 August 2014 - Published: 19 September 2014

\begin{abstract}
Preliminary attempts of quantifying the stratospheric ozone contribution in the observations at the Zugspitze summit (2962 ma.s.1.) next to GarmischPartenkirchen in the German Alps had yielded an approximate doubling of the stratospheric fraction of the Zugspitze ozone during the time period 1978 to 2004. These investigations had been based on data filtering by using low relative humidity $(\mathrm{RH})$ and elevated ${ }^{7} \mathrm{Be}$ as the criteria for selecting half-hour intervals of ozone data representative of stratospheric intrusion air. To quantify the residual stratospheric component in stratospherically influenced air masses, however, the mixing of tropospheric air into the stratospheric intrusion layers must be taken into account. In fact, the dewpoint mirror instrument at the Zugspitze summit station rarely registers RH values lower than $10 \%$ in stratospheric air intrusions. Since 2007 a programme of routine lidar sounding of ozone, water vapour and aerosol has been conducted in the Garmisch-Partenkirchen area. The lidar results demonstrate that the intrusion layers are drier by roughly one order of magnitude than indicated in the in situ measurements. Even in thin layers RH values clearly below $1 \%$ have frequently been observed. These thin, undiluted layers present an important challenge for atmospheric modelling. Although the ozone values never reach values typical of the lower-stratosphere it becomes, thus, obvious that, without strong wind shear or convective processes, mixing of stratospheric and tropospheric air must be very slow in most of the free troposphere. As a consequence, the analysis the Zugspitze data can be assumed to be more reliable than anticipated. Finally, the
\end{abstract}

concentrations of Zugspitze carbon monoxide rarely drop inside intrusion layers and normally stay clearly above full stratospheric values. This indicates that most of the $\mathrm{CO}$, and thus the intrusion air mass, originates in the shallow "mixing layer" around the thermal tropopause. The $\mathrm{CO}$ mixing ratio in these descending layers between 1990 and 2004 exhibits a slightly positive trend indicating some Asian influence on the lowermost stratosphere in the high-latitude source region of most intrusions reaching the station.

\section{Introduction}

The increase of ozone and ${ }^{7} \mathrm{Be}$ at the Alpine summit station Zugspitze (2962 m a.s.l., Garmisch-Partenkirchen, Germany) between the mid-1970s and 2002 (Oltmans et al., 2006, 2012; Logan et al., 2012; Parrish et al., 2012) has led to systematic efforts to identify and quantify the causes. During the decade after 1990, the ozone precursor emissions in Europe were on a decline (e.g. Jonson et al., 2006; Vautard et al., 2006; and references therein), in contrast to the Zugspitze ozone. However, data filtering by Scheel (2002, 2003; pp. 66-71 in ATMOFAST, 2005), based on the ozone, relative humidity $(\mathrm{RH})$ and ${ }^{7} \mathrm{Be}$ measurements, has shown that the only strong positive trend in the Zugspitze ozone between 1990 and 2002 is related to air descending in deep stratospheric intrusions. Similar conclusions were published by Ordoñez et al. (2007) for the Jungfraujoch station ( $3580 \mathrm{~m}$ a.s.l.) in the Swiss Alps for the time period between late 1992 and 2004. At the lower-lying station 
Wank (1780 m a.s.l., also next to Garmisch-Partenkirchen) no ozone trend is seen at all between 1984 and 2004 reflecting the much lower stratospheric influence at that altitude (Elbern et al., 1997). However, the decreasing emissions during the 1990s are reflected by a decreasing amplitude of the seasonal cycle (Scheel, 2003).

A positive trend of the stratospheric component was found for the Zugspitze ozone record since the beginning of the measurements in 1978, accompanied by an increase in ${ }^{7} \mathrm{Be}$ since the late 1970s. The preliminary analysis suggests that the overall stratospheric ozone contribution at the Zugspitze summit has almost doubled from about 11 to $20 \mathrm{ppb}$ since 1978 (ATMOFAST, 2005), the first value being in agreement with background mixing ratios reported for the late 19th century (Volz and Kley, 1988). The corresponding fraction relative to the annual mean ozone value of approximately $40 \%$ matches the global modelling results of Roelofs and Lelieveld (1997) for the entire troposphere. The importance of stratosphere-to-troposphere transport (STT) for the tropospheric ozone budget has also been underlined in a recent study of specific high-ozone layers in the middle and upper troposphere over Garmisch-Partenkirchen presumably fed by STT along the subtropical jet stream (Trickl et al., 2011). STT along the subtropical jet stream is a particularly abundant source of STT (Sprenger et al., 2003).

So far, the data-filtering efforts underlying the determination of the stratospheric influence in the Zugspitze ozone record have neglected the mixing of tropospheric air into the intrusion layers (see Trickl et al., 2010 for a comparison of different filtering criteria with daily model forecasts). However, since a RH clearly below $10 \%$ has been only occasionally recorded at the mountain site there has been some debate on how much tropospheric air enters these descending air streams and on how to account for the resulting bias. In fact, the ozone mixing ratios observed in stratospheric intrusion layers reaching the Zugspitze summit are mostly much lower than the ozone mixing ratios in the lower stratosphere.

The existence of mixing has been reported in a number of publications. Shapiro (1980) examined the role of turbulent mixing in a tropopause fold examined above $6 \mathrm{~km}$ due to the strong wind shear next to the jet stream. Predominant contributions to the turbulent exchange were concluded to be caused by low-frequency components rather than by the small-scale eddies associated with clear-air turbulence. A mixing zone in the tropopause region has been postulated, and the resulting chemical composition has been investigated in numerous studies (e.g. Danielsen, 1968; Shapiro, 1976, 1978, 1980; Lelieveld et al., 1997; Hintsa et al., 1998; Zahn et al., 1999; Fischer et al., 2000; Hoor et al., 2002, 2004; Pan et al., 2004, 2007; Brioude et al., 2006, 2008; Sprung and Zahn, 2010; Hegglin et al., 2009; Vogel et al., 2011). The development of aerosol layers - of volcanic origin, from biomass burning or from deserts - around the tropopause is discussed by Trickl et al. (2013). Mixing of intrusion layers with surrounding air is also expected to occur in the tropo- sphere (see overview by Stohl et al., 2003b). In some cases mixing of polluted air into intrusions within the free troposphere has been reported (e.g. Parrish et al., 2000; Brioude et al., 2007). Brioude et al. (2006) analyse the complex chemical composition of the air streams in the vicinity of an extratropical low. Stohl et al. (2007) discuss a case of turbulent mixing over Europe between a stratospheric intrusion and a polluted air mass from Southeast Asia. The mixing was observed in airborne air-chemistry measurements in a region where the aircraft encountered turbulence and where the Richardson number - an indicator for possible occurrence of turbulence - was below 0.2. Mixing due convective activity was found by Cooper et al. (2005) and Homeyer et al. (2011). On the other hand, Bithell et al. (2000) report on a very dry layer of presumably stratospheric origin that had persisted in the troposphere for at least 10 days.

Lidar sounding has played an important role in the strong revival of the investigation of STT and has also contributed insight into the impact of free-tropospheric long-range transport on the vertical distribution of atmospheric constituents, in particular ozone, water vapour and aerosol. In groundbased lidar time series (e.g. Langford et al., 1996; Eisele et al., 1999; Trickl et al., 2003, 2010; Zanis et al., 2003; Kuang et al., 2012) the $\mathrm{O}_{3}$ mixing ratio in stratospheric intrusions drops from typically 100 to $150 \mathrm{ppb}$ in the middle and upper troposphere to roughly half the value or less at (e.g.) $3000 \mathrm{~m}$, sometimes within just half a day. The low values at around $3000 \mathrm{~m}$ match those observed at the high-lying summit stations.

By combining different lidar or vertical sounding methods complementary information on the character of specific air layers may be obtained (e.g. Browell et al., 1987, 1996, 2001; Trickl et al., 2003, 2011; Flentje et al., 2005). Although aerosol was observed in a stratospheric air intrusion after the El Chichón volcanic eruption (Browell et al., 1987) the most important STT tracers accessible by lidar sounding are ozone and water vapour. Intrusion layers are characterized by elevated ozone and low water vapour - the mixing ratios of both, however, significantly deviating from the lower-stratospheric values of several hundred parts per billion for ozone and 4 to $5 \mathrm{ppm}$ for water vapour (e.g. Scherer et al., 2008).

Investigation of the humidity in a stratospheric intrusion layer may also be seen as a possibility for evaluating freetropospheric mixing in models. Such an assessment is highly desirable since models tend to overestimate mixing into thin layers due to their limited spatial resolution and (in Eulerian models) numerical diffusion (e.g. Stohl et al., 2004; Rastigejev et al., 2010). Solving the problems with mixing is an important step in view of a quantification of the impact of deep STT on the chemical composition of the troposphere.

Simultaneous lidar measurements of ozone and water vapour have been reported for airborne systems only (e.g. Browell et al., 1996, 2001). In this paper, we report on recent simultaneous ground-based lidar measurements of ozone and water vapour in the Garmisch-Partenkirchen area (Bavarian 
Alps, Germany), combined with Zugspitze in situ measurements of ozone, $\mathrm{RH}$ and $\mathrm{CO}$, and with model results to gain further insight into the details of intrusion layers. We present results on the considerable dryness of deep stratospheric intrusions even in thin layers, as indicated by Vogelmann and Trickl (2008), strongly questioning the results of the in situ $\mathrm{RH}$ measurements. We address the issue of why, by contrast, ozone in layers descending from the stratosphere to the lower troposphere rarely exhibit very high concentrations.

\section{Mixing in tropopause folds and tropopause definitions}

Shapiro (1976, 1978, 1980) concluded from airborne measurements that significant turbulent structures exist in situations when the stratospheric air tongue entering the troposphere is, still, adjacent to the jet stream. These structures are caused by the considerable wind shear and horizontally cover about $100 \mathrm{~km}$. They are also characterized by a transition of the ozone mixing ratio from stratospheric to tropospheric values. Figure 9 of Shapiro (1980) shows ozone and condensation nuclei during a flight through a tropopause fold at a pressure level of $366 \mathrm{mbar}$ (about $7.9 \mathrm{~km}$, i.e. possibly in an early phase of the descent). At the centre of the fold the density of the condensation nuclei, $200 \mathrm{~cm}^{-3}$, was about 10 times smaller than that outside the fold, and ozone maximized at $248 \mathrm{ppb}$. Towards the edges the number of nuclei grew and ozone diminished. Shapiro estimates a $50 \%$ ozone loss to the adjacent tropospheric layers (a value confirmed by Vogel et al. (2011) based on flight data for $\mathrm{O}_{3}$ and $\mathrm{CO}$ and model calculations). No values inside the fold are specified for lower altitudes. Condensation nuclei densities in the lowermost stratosphere were 50 to $100 \mathrm{~cm}^{-3}$ (Fig. 3 of Shapiro, 1980). Thus, the enhancement must be ascribed to some additional tropospheric input.

Shapiro does not address the question of how much of the "tropospheric" component was already present before the air mass reached the region of descent. Clearly, the tropopause upstream of a fold is not a rigid barrier between the troposphere and the stratosphere. Vertical exchange in both directions occurs, forming a transition region (see literature cited in the Introduction).

In the absence of ozone plumes advected just below the tropopause we regard the onset of the strong ozone rise towards higher altitudes as the tropopause since the definition of the stratosphere is related to ozone. Examples show that the rise in ozone is well correlated with that of the potential vorticity and that the first, strong rise of the potential vorticity can even start at about 1 pvu (potential vorticity units; $1 \mathrm{pvu}=10^{-6} \mathrm{~K} \mathrm{~m}^{2} \mathrm{~kg}^{-1} \mathrm{~s}^{-1}$ ) or even below (e.g. Danielsen et al., 1987; Pan et al., 2004). It is, thus, common practice in model-assisted investigations to use a potential-vorticity threshold to define the tropopause (dynamical tropopause), in particular in the vicinity of tropopause folds where the use of the thermal tropopause is not reasonable (see Kuang et al., 2012, for a recent example). The World Meteorological Organization recommends a more robust threshold of $1.6 \mathrm{pvu}$ for the dynamical tropopause (WMO, 1986). Hoerling et al. (1991) determined that $3.5 \mathrm{pvu}$ is the best value for representing the extratropical thermal tropopause. For the studies of our team since 1996 a conservative threshold of $2.0 \mathrm{pvu}$ has been used for the dynamic tropopause, and this is continued here for consistency.

Zahn and Brenninkmeijer (2003) go a different way and define a chemical tropopause by correlating $\mathrm{O}_{3}$ and $\mathrm{CO}$. They found in the abundant CARIBIC (Civil Aircraft for the Regular Investigation of the Atmosphere Based on an Instrument Container) flight data a sharp transition between positive correlation (troposphere) and negative correlation (stratosphere). Pan et al. (2004) concluded from numerous research flights between the Tropics and Arctic regions that the chemical transition is rather well centred around the thermal tropopause, whereas the 2 pvu tropopause is located 1 to $3 \mathrm{~km}$ lower. As is also known from the operational radiosonde ascents, slightly elevated water vapour typically extends to 1 to $3 \mathrm{~km}$ above the thermal tropopause.

In agreement with the findings reported in the literature our long-term aerosol observations (Jäger, 2005; Trickl et al., 2013) have often revealed structures concentrated around the thermal tropopause, presumably caused by volcanic eruptions or fire plumes just reaching the tropopause region. In addition, during the years after the Pinatubo eruption stratospheric aerosol frequently "leaked" 2 to $3 \mathrm{~km}$ below the thermal tropopause. This behaviour is confirmed by our observations with the ozone lidar. However, sharp cut-offs within a few hundred metres below the thermal tropopause exist for both species.

More information on the research on the tropopause region can be found in a recent review by Gettelman et al. (2011).

\section{Methods}

\subsection{Measurements}

The tropospheric ozone lidar is operated in GarmischPartenkirchen, Germany (IMK-IFU, formerly IFU; $47^{\circ} 28^{\prime} 37^{\prime \prime} \mathrm{N}, 11^{\circ} 3^{\prime} 52^{\prime \prime} \mathrm{E}, 740 \mathrm{~m}$ a.s.1.). The laser source is a Raman-shifted $\mathrm{KrF}$ laser, and two separate receiving telescopes are used to divide the dynamic range of the backscatter signal of roughly eight decades. This lidar was completed as a two-wavelength differential absorption lidar (DIAL) in 1990 (Kempfer et al., 1994). It was upgraded to a three-wavelength DIAL in 1994 and 1995 (Eisele and Trickl, 1997, 2005), leading to a unique vertical range between roughly $0.2 \mathrm{~km}$ above the ground and 3 to $5 \mathrm{~km}$ above the tropopause, the measurement time interval being just $41 \mathrm{~s}$. It features low uncertainties of about $\pm 3 \mathrm{ppb}$ in the lower free troposphere, growing to $\pm 6 \mathrm{ppb}$ (under optimum conditions) in the upper troposphere. The uncertainty further 
diminished after a system upgrade in 2012, with the introduction of a new ground-free input stage to our transient digitizers (Licel) that reduced the noise level by more than a factor of three. For the range covered by the near-field receiver (below $1.2 \mathrm{~km}$ above the lidar) the uncertainty is of the order of $\pm 6 \mathrm{ppb}$. Comparisons with the Zugspitze in situ measurements (see below) show no relevant mutual bias, the standard deviation of the differences being less than $2 \mathrm{ppb}$. The upper-tropospheric performance may be degraded in the presence of high lower-tropospheric ozone concentrations absorbing a lot of the ultraviolet laser emission and by enhanced sky light in summer, in particular in the presence of clouds. Thus, longer data acquisition times, requiring some technical modifications, are planned for the future. The vertical resolution is dynamically varied between $50 \mathrm{~m}$ and a few hundred metres, depending on the signal-to-noise ratio decreasing with altitude. The lidar has been used in numerous atmospheric transport studies (e.g. Eisele et al., 1999; Seibert et el., 2000; Carnuth et al., 2002; Trickl et al., 2003, 2010, 2011; Zanis et al., 2003).

The water-vapour DIAL is operated at the Schneefernerhaus high-altitude research station at $2675 \mathrm{~m}$ a.s.l., about $8.5 \mathrm{~km}$ to the southwest of IMK-IFU, $0.7 \mathrm{~km}$ to the southwest of and about $300 \mathrm{~m}$ below the Zugspitze summit (2962 ma.s.1.). Full details of this lidar system were described by Vogelmann and Trickl (2008). This lidar system is based on a powerful tunable narrow-band Ti:sapphire laser system with up to $250 \mathrm{~mJ}$ energy per pulse (typical choice: $100 \mathrm{~mJ}$ ) operated at about $817 \mathrm{~nm}$ and a $0.65 \mathrm{~m}$ diameter Newtonian receiver. Due to these specifications a vertical range up to about $12 \mathrm{~km}$ is achieved, almost independent of the solar background, with measurement durations of about $15 \mathrm{~min}$. The vertical resolution chosen in the data evaluation is dynamically varied between $50 \mathrm{~m}$ in altitude regions with good signal-to-noise ratio and roughly $260 \mathrm{~m}$ in the upper troposphere. Under optimum conditions the noise limit above $10 \mathrm{~km}$ a.s.l. corresponds to uncertainties of about $\pm 1.5 \times 10^{20} \mathrm{~m}^{-3}$ (density) or about $18 \mathrm{ppm}$ (volume mixing ratio). In the lowermost part of the operating range (3 to $4 \mathrm{~km}$ ) we estimate a density noise limit of $\pm 5 \times 10^{20} \mathrm{~m}^{-3}$ or roughly $\pm 25 \mathrm{ppm}$ for layers with very low humidity. Under average temperature conditions this corresponds to about $\pm 0.5 \%$ RH. Under humid conditions we estimate a relative uncertainty of about $5 \%$. Free-tropospheric measurements clearly benefit from the elevated site outside or just below the edge of the moist Alpine boundary layer (e.g. Carnuth and Trickl, 2000, 2002). After a few years of testing, validating and optimizing the system, routine measurements were started in January 2007 with typically two measurement days per week, provided that the weather conditions are favourable. During this period also successful comparisons with an airborne DIAL and a ground-based Fouriertransform infrared spectrometer (Wirth et al., 2009; Vogelmann et al., 2011) were achieved verifying average mutual biases of not more than $1 \%$.
In addition, in situ data from the monitoring station at the Zugspitze summit are used, in particular ozone, $\mathrm{CO}$ and $\mathrm{RH}$. Ozone has been measured since 1978 (e.g. Reiter et al., 1987; Scheel et al., 1997; Oltmans et al., 2006, 2012). A chemiluminescence instrument (Bendix 8002, Bendix Corporation, USA) was in operation until 1999. Thereafter, only ultraviolet absorption instruments have been employed (TE49 analysers, Thermoelectron, USA). The uncertainty level of the ozone measurements is less than $1 \mathrm{ppb}$. CO has been measured since 1990, using instrumentation based on gas chromatography with a mercury reduction detector (RGD2, Trace Analytical, USA) or gas filter correlation infrared absorption (TE48S, Thermo Electron, USA) as well as vacuum resonance fluorescence (AL5001, AeroLaser, Germany). Two different systems have been running in parallel for most of the time. RH is measured with a dewpoint mirror (Thygan VTP6, Meteolabor, Switzerland) with a quoted uncertainty below $5 \%$ RH.

\subsection{Models}

Daily STT forecasts for a number of European observational sites have been made with a trajectory model by ETH Zürich since late in the year 2000 (Zanis et al., 2003; Trickl et al., 2010), started within the STACCATO project (Stohl et al., 2003b). Since June 2001 so-called "intrusion hit tables" have been additionally distributed giving a crude estimate of the time-height development of stratospheric air above the four partner stations Jungfraujoch, Zugspitze, Monte Cimone and Thessaloniki over several days. The stratospheric air intrusions presented here also were forecast in this way. On each day, trajectories are calculated with the Lagrangian Analysis Tool (LAGRANTO; Wernli and Davies, 1997) for the start times 00:00 and 12:00 UTC, as well as for 00:00 and 12:00 UTC on the following day, using operational forecast data from the European Centre for Medium-Range Weather Forecasts (ECMWF) with $1^{\circ} \times 1^{\circ}$ resolution. For each start time 4-day forward trajectories are calculated, starting in the entire region covering the Atlantic Ocean and western Europe $\left(20^{\circ} \mathrm{E}\right.$ to $80^{\circ} \mathrm{W}$ and $\left.40-80^{\circ} \mathrm{N}\right)$ between 250 and 600 mbar. From this large set of trajectories those initially residing in the stratosphere (potential vorticity larger than $2.0 \mathrm{pvu}$ ) and descending during the following 4 days by more than 300 mbar into the troposphere were selected as "stratospheric intrusion trajectories". The same selection criterion was used in a previous case study (Wernli, 1997) to study an intrusion associated with a major North Atlantic cyclone.

For the cases of the present study, the LAGRANTO calculations were repeated, based on the ECMWF ERA-Interim re-analysis data set (Dee et al., 2011), at intervals of $6 \mathrm{~h}$ starting at 00:00 UTC on each day. The trajectory time period was extended from 4 to 5 days. This results in an enhanced number of trajectories accepted by the algorithm because of a higher probability of descent below the threshold altitude. 
In addition, backward analyses were carried out. For long transport paths trajectory analyses based on a moderate number of trajectories become less meaningful due to increasingly bad geographical coverage and the neglect of turbulent mixing. As a consequence backward options of the Lagrangian particle dispersion model FLEXPART (Stohl et al., 1998, 2005) have been developed and successfully applied (early examples: Stohl et al., 2003a; Trickl et al., 2003; Huntrieser et al., 2005). Turbulence and convection in the planetary boundary layer (PBL) as well as moist convection throughout the atmosphere are accounted for in the FLEXPART model. The so-called retroplumes yield a much more complete picture of where the air masses come from than simple trajectory calculations. The model output of a FLEXPART backward calculation is a 4-D emission sensitivity field which is proportional to the residence time of the particles. Longer residence times mean a higher sensitivity to the local emissions. Altitudes of $500 \mathrm{~m}$ and less, as used in the investigations presented here, can be used to identify areas of potential emission uptake from the surface. By folding the emission sensitivity with emission fluxes from appropriate inventories the source regions may be highlighted. For the simulations carried out within this work the EDGAR 3.2 fasttrack inventory for the year 2000 (Olivier and Berdowski, 2001) has been used. Within this study, the potential influence of the East Asian PBL on two intrusion layers has been investigated, but no indication was found.

In the present study particles were released in $200 \mathrm{~m}$ bins in the air column above Garmisch-Partenkirchen, up to $12 \mathrm{~km}$ a.s.l., and every hour during observation periods. The backward simulations are carried out for periods of 20 days. They include a full "retroplume analysis" as described by Stohl et al. (2002a). Both the mean horizontal and vertical position of up to five clusters of the retroplume for a $200 \mathrm{~m}$ bin are given as well as the fraction of air coming from the PBL and from the stratosphere (threshold $2.0 \mathrm{pvu}$, polewards of $30^{\circ}$ ) as a function of backward time. Tables of the vertical distribution of the stratospheric air fractions were generated at $1 \mathrm{~h}$ intervals during the observational periods. The average values of the stratospheric fractions values were given for four backward time intervals: $0-5,5-10,10-15$ and $15-$ 20 days.

\section{Results}

Stratospheric air intrusions have been observed above Garmisch-Partenkirchen on more than 200 days since 1996 either with the ozone DIAL (e.g. Eisele et al., 1999; Zanis et al., 2003; Trickl et al., 2010), the water-vapour DIAL (first examples: Vogelmann and Trickl, 2008), or both systems. For example, in 2013 free-tropospheric ozone peaks on roughly $60 \%$ of the measurement days have been attributed to air subsiding from the tropopause region. This underlines the importance of STT for the tropospheric ozone budget, in par- ticular since strong pollution-related ozone peaks seem to be on the decline.

In the majority of the intrusion cases observed over Garmisch-Partenkirchen the descent of the stratospheric layer to the lower troposphere occurs prior to the arrival of the stratospheric intrusion at the northern rim of the Alps, particularly for the start of the subsidence over Canada or even farther to the west (Types 5 and 6 as classified by Trickl et al. (2010) based on source regions). In some cases the departure of the descending layer from the tropopause could also be followed. In these cases the intrusion occurred closer to the Alps or the stratospheric air stayed in the tropopause region much longer and descended in a late phase. In the case of a "classical" direct intrusion (Type 1 as defined by Trickl et al., 2010) the stratospheric air anticyclonically descends from Greenland to the Alps, and the intrusion layer exhibits some east-west inclination (Reiter et al., 1970-1977), with high ozone concentrations at the eastern edge and moderate ones at the lower-lying western edge that hits the Alpine summits. The subsidence observed with the lidar systems in previous studies (e.g. Eisele et al., 1999; Zanis et al., 2003; Trickl et al., 2010) is to a major extent due to an eastward drift of the layer roughly perpendicular to the principal direction of the air mass propagation. Most stratospheric air intrusions starting outside Europe and passing over the Northern Alps hit the Zugspitze summit (2962 ma.s.1.; Trickl et al., 2010). The peak ozone mixing ratio observed here rarely exceeds $80 \mathrm{ppb}$.

In what follows we first briefly discuss three intrusion cases deviating from the ideal picture of homogeneous descending layers. These cases are characterized by splitting of the intrusion layers into thin filaments. Even under these conditions the centres of the air masses were found to be extremely dry, exhibiting almost no sign of mixing with the moister tropospheric air. In Sect. 4.4 we then summarize the results for the measurements with the water-vapour DIAL obtained for quite a variety of deep stratospheric intrusions since 2004. Finally, in Sect. 4.5, we add a short section on the CO level and trend in intrusions as observed at the Zugspitze summit between 1990 and 2004 .

\subsection{March 2008}

\subsubsection{Lidar measurements}

The first series of simultaneous ozone and water-vapour measurements at Garmisch-Partenkirchen took place during a particularly spectacular and complex intrusion period exhibiting in three layers the highest ozone mixing ratios ever seen in lidar measurements of stratospheric intrusions above Garmisch-Partenkirchen during the past 15 years. The results from both lidar systems and the summit station are shown in Figs. 1, 3 and 4. Figure 2 shows a FLEXPART model calculation, described further below, that captures the main features of the lidar series. Figure 5 shows an example of 


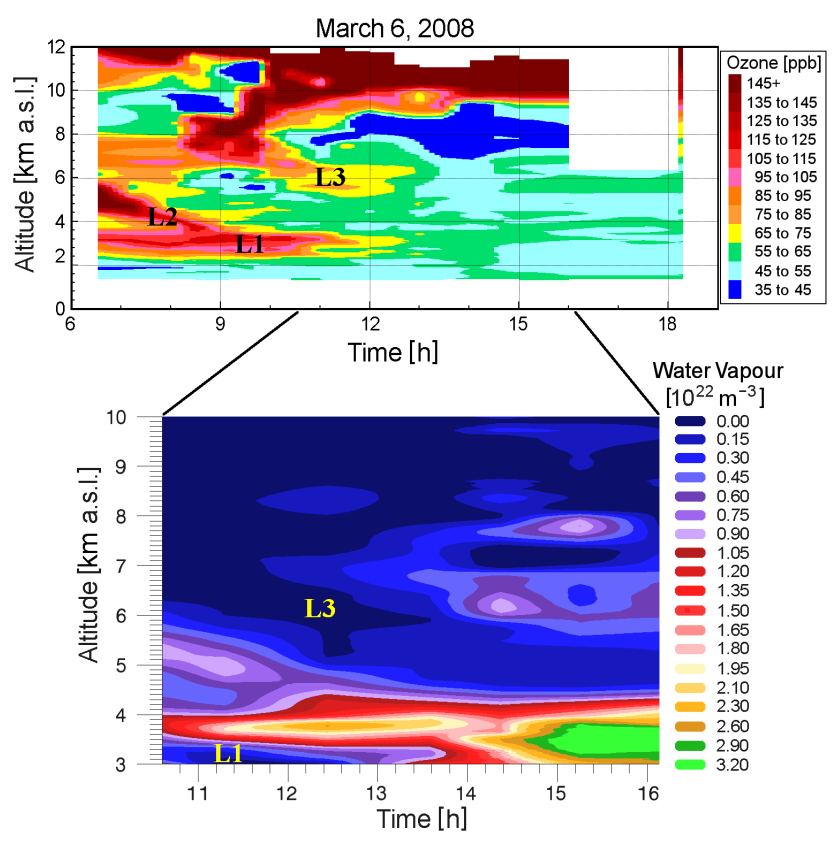

Figure 1. Ozone and water-vapour sounding series on 6 March 2008, showing three high-ozone (low-humidity) layers (L1-L3) caused by a stratospheric air intrusion system; the time is given with respect to 00:00 CET (Central European Time, $=\mathrm{UTC}+1 \mathrm{~h}$ ). The numbers denoting the colour of a given $\mathrm{H}_{2} \mathrm{O}$ density range correspond to the respective lower boundary.

LAGRANTO forward trajectory calculations based on reanalysis data (see below).

The maximum ozone mixing ratios retrieved for Layers L1-L3 (upper panel of Fig. 1) are 122, 177 and $195 \mathrm{ppb}$, respectively (Fig. 3). The ozone measurements were started rather late, at 06:32 CET (Central European Time, $=\mathrm{UTC}+1 \mathrm{~h})$ on 6 March when a period of rapid subsidence of the huge ozone peak of Layer L2 was already approaching its end.

The water-vapour measurements (lower panel of Fig. 1) were started at 10:30 CET due to the delay caused by the travel to the high-altitude station and the partial removal of roughly $2 \mathrm{~m}$ of fresh snow. The retrieved $\mathrm{H}_{2} \mathrm{O}$ densities show a considerable similarity in the temporal development of the layering with that of ozone. The two layers still visible after the beginning of the measurements, L1 and L3, are characterized by extremely low humidity sometimes reaching zero. The density unit of the colour scale, $0.15 \times 10^{22} \mathrm{~m}^{-3}$, corresponds to mixing ratios of about $78 \mathrm{ppm}$ at $3.0 \mathrm{~km}$ and $111 \mathrm{ppm}$ at $6.2 \mathrm{~km}$ (RH 1.6 and $7.7 \%$, respectively).

It is interesting to note that the dry layer L3 can be followed much longer in the $\mathrm{H}_{2} \mathrm{O}$ data than indicated by the corresponding high- $\mathrm{O}_{3}$ values. The strongly dropping ozone and the slightly rising humidity could indicate a transition from air of stratospheric origin to air of upper-tropospheric origin.

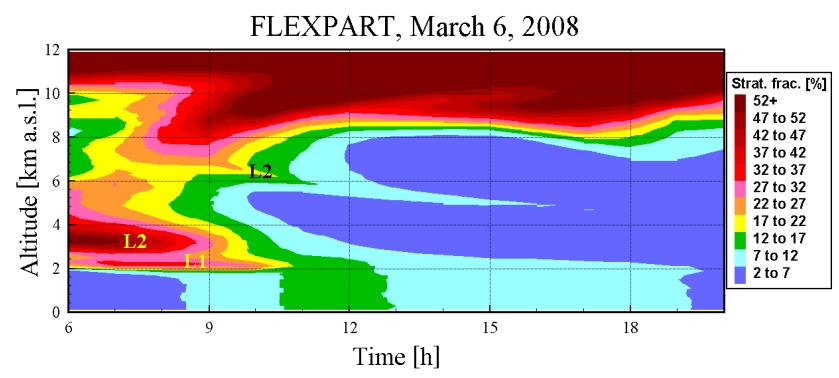

Figure 2. FLEXPART stratospheric fractions for the period shown in Fig. 1, obtained from 20-day retroplume calculations.

\subsubsection{Zugspitze data}

The top of the lowest ozone peak did not fully reach the Zugspitze summit, but, still, $101.9 \mathrm{ppb}$ were registered at the summit station at 09:30 CET (Fig. 4), one of the highest values ever recorded at this station during intrusions. The RH at the station did not drop below $14 \%$ which strongly contrasts the lidar measurements that show zero minimum RH. This fact will be further discussed in Sects. 4.4 and 5. For comparison, the minimum RH from the radiosonde ascents at Oberschleißheim ("Munich" sonde, $100 \mathrm{~km}$ roughly to the north of IMK-IFU) is $1 \%$. A look at recent sonde data, in general, shows that, for unknown reasons, $1 \%$ is the lowest value tabulated by the German Weather Service.

It is interesting to note that the Zugspitze CO drops during the period of highest ozone. Such a drop during an intrusion is not always clearly seen - see also Trickl (2010) and the other examples in this paper. However, the minimum CO value of $110 \mathrm{ppb}$ is considerably higher than the $\mathrm{CO}$ mixing ratios between 20 and $40 \mathrm{ppb}$ reported for the stratosphere (e.g. Zahn et al., 1999; Fischer et al., 2000; Pan et al., 2004; Hegglin et al., 2009; Vogel et al., 2011). This suggests that even strong intrusions such as the one presented here originate in the mixing zone extending up to 3 to $5 \mathrm{~km}$ above the thermal tropopause (Hoor et al., 2002; Sprung and Zahn, 2010). Due to the low humidity determined with the lidar a strong mixing with tropospheric air during the descent to Europe is unlikely.

\subsubsection{Model results}

The LAGRANTO trajectory calculations reveal a filamentary structure with Garmisch-Partenkirchen being located underneath the easternmost filament of the southward branch of the intrusion (Fig. 5). The filament exhibits trajectories passing at a variety of altitudes, depending on the start time. However, the trajectory density is too to show the details seen in the observations.

The most important message is that the stratospheric filaments are spatially rather confined, but despite this fact very high ozone values and very low humidity were observed. These air masses were clearly not subject to significant 
mixing with the surrounding tropospheric air during their travel from Greenland to the Alps.

FLEXPART 20-day retroplume calculations were used to evaluate the stratospheric air mass fraction for the observational period shown in the upper panel of Fig. 1 (Fig. 2). The average fractions for the four 5-day backward time periods $(0-5,5-10,10-15,15-20$ days) are almost equal, which suggests that the intrusion air was of truly stratospheric origin and descended through the tropopause only during the last 5 days before the arrival. The highest values were, however, obtained for the 0-5 and 5-10-day intervals, suggesting that some of the air may have been in the stratosphere for only a few days. Therefore, in Fig. 2 we give the results just for the first backward time interval. Apart from some vertical displacement of layers L1 and L2 the agreement is excellent. As expected from the high ozone levels measured with the lidar, the maximum stratospheric fractions are of the order of $50 \%$ and, thus, reasonably high.

Very importantly, the drop in the FLEXPART fractions around noon in Layer L2 almost matches in time the ozone cut-off. At the same time the water-vapour density starts to grow. This reflects a transition from a more stratospheric to a tropospheric nature of the air mass. It is reasonable to assume that this behaviour was imported from the Arctic source region.

\subsection{6 to 27 December 2008}

\subsubsection{Lidar measurements}

A particularly thin intrusion passed over Central Europe on 26 and 27 December 2008 (Fig. 6). The layer differed from all others observed since the beginning of our focused studies in 1996 by the combination of two properties: it could be observed all the way down from the tropopause to $3 \mathrm{~km}$ and was very thin even in the upper troposphere. Again, a FLEXPART run nicely verifies the measurements (Fig. 7; details: see further below). Nevertheless, the same drop in ozone concentration took place as in all cases in which strong subsidence was observed with the lidar. In the upper troposphere the mixing ratio was about $160 \mathrm{ppb}$ (09:00 CET). The ozone values dropped to values of about $90 \mathrm{ppb}$ until noon and roughly $60 \mathrm{ppb}$ during the early hours of 27 December, when the layer had descended to $3.2 \mathrm{~km}$. Towards the end a slight rise was observed.

The water-vapour DIAL was not available because the Schneefernerhaus station was closed over Christmas. Instead, we give in Fig. 8 the two Vaisala RS-92 sonde measurements at Oberschleißheim on 26 December at 13:00 CET (12:00 UTC) and on 27 December at 01:00 CET. Despite the considerable distance between the lidar and the sonde station the agreement of the layer positions for the two launch times is satisfactory which could be due to an approximate east-west propagation of the air stream (see LAGRANTO trajectories further below). The descent of the intrusion layer

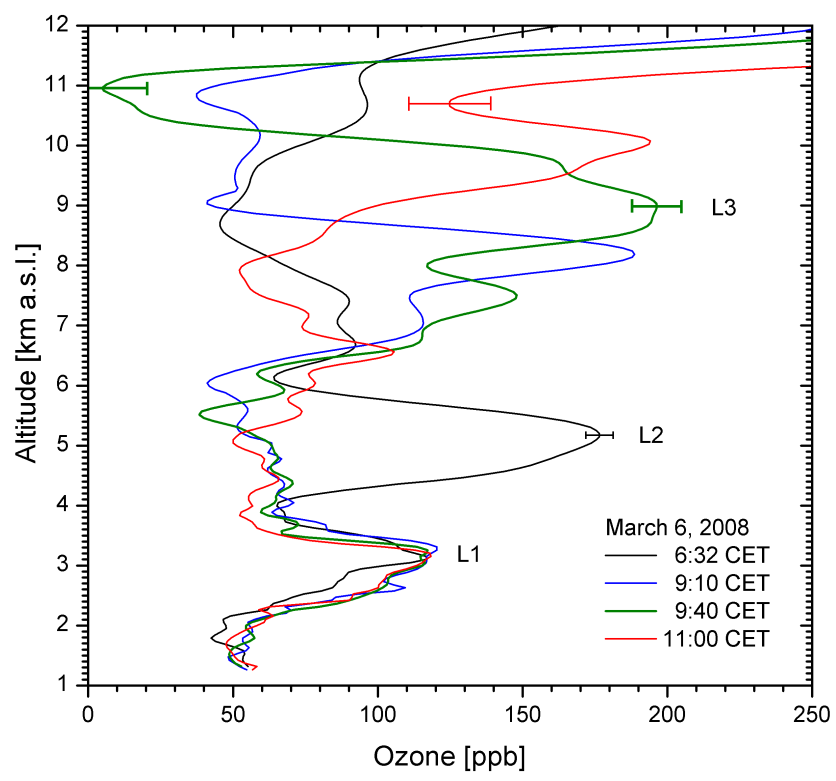

Figure 3. Selected ozone profiles from the measurement series shown in the upper panel of Fig. 1; a few error bars representative for the respective altitude ranges are given for a judgement of the data quality that is influenced by the strong light absorption in the intrusion layers. The Munich thermal tropopause was located at $11.3 \mathrm{~km}$ at 01:00 CET (00:00 UTC) and at 10.6 km at 13:00 CET.

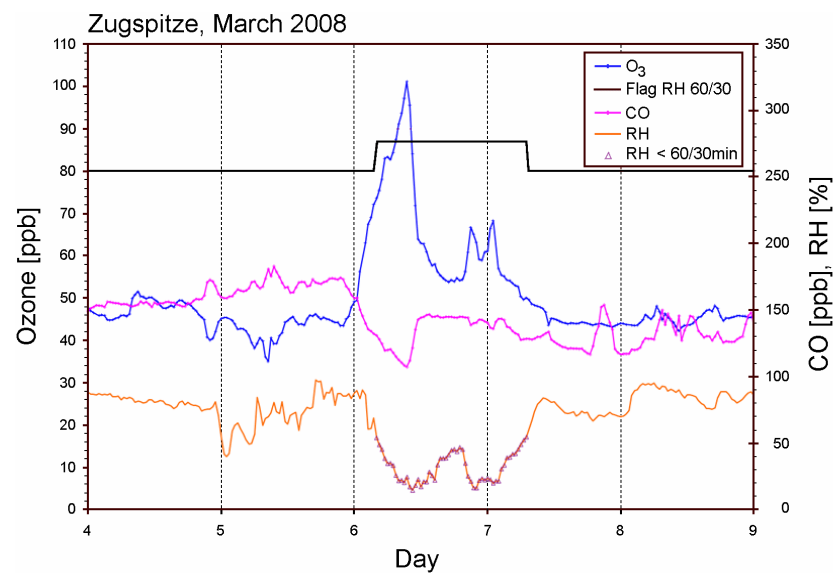

Figure 4. Zugspitze ozone, CO and RH in early March 2008; the range of elevated values in the black top trace indicates the period of STT according to filtering Criterion 2 of (Trickl et al., 2010), i.e. $\mathrm{RH}<60 \%$ and $\mathrm{RH}<30 \%$ within the adjacent $6 \mathrm{~h}$. The violet triangles on the $\mathrm{RH}$ curve also mark the time period during which Criterion 2 was valid. Despite the remarkable ozone rise, the CO mixing ratio stays far above full stratospheric values of 20 to $40 \mathrm{ppb}$. 


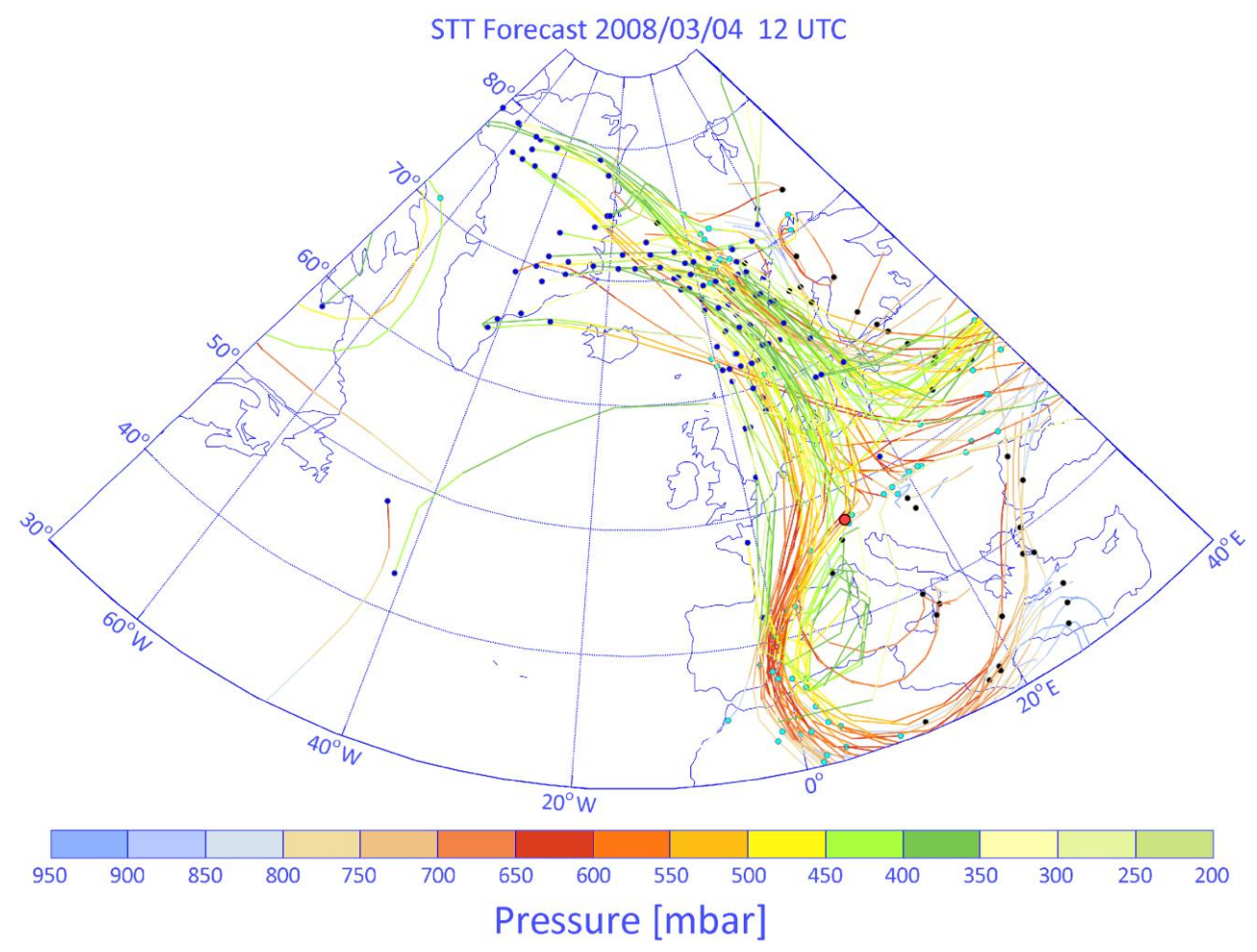

Figure 5. The 5-day LAGRANTO intrusion trajectories, based on ECMWF re-analysis data: the trajectories were initiated on 4 March 2008 , at $t_{\mathrm{O}}=12: 00 \mathrm{UTC}(13: 00 \mathrm{CET})$. The time positions on the trajectories for $t_{\mathrm{O}}, t_{\mathrm{O}}+2$ day and $t_{\mathrm{o}}+4$ day are marked by dark blue, light blue and black dots, respectively. The position of Garmisch-Partenkirchen is marked by a red dot. It is reached almost exactly 2 days after $t_{\mathrm{O}}$. The pressure level of $700 \mathrm{mbar}$ corresponds to an altitude of approximately $3 \mathrm{~km}$ (Zugspitze).

and its considerable dryness are clearly documented. Again, $1 \% \mathrm{RH}$ is the lowest value listed.

\subsubsection{Zugspitze data}

The intrusion layer was clearly verified at the Zugspitze summit between 26 December, 21 CET, and 27 December, 4 CET (Fig. 9). There is a steep rise in ozone from 42 to $49 \mathrm{ppb}$ on 26 December and then a less pronounced increase in the afternoon of 27 December. The minimum RH was 30 and $26 \%$, respectively. However, a quantitative comparison is not possible since the lidar data in Fig. 7 suggest that the peak of the layer passed slightly above the summit station.

\subsubsection{Model results}

As in the case study presented in Sect. 3.1 the LAGRANTO trajectory calculations indicate some filamentation (Fig. 10). The filament observed propagates around the eastern side of an anticyclone and finally very rapidly descends towards the station in almost zonal orientation. The role of a transverse component in the layer descent of Fig. 6, which is an important factor in many lidar observations of stratospheric intrusions, could not be identified due to an insufficient resolution of the model results.
The FLEXPART results (Fig. 7) reproduce the thin structure of the intrusion layer. However, the stratospheric fractions are significantly lower than in the first case. Again, the average fractions do not differ very much on the absolute scale. But this time the maximum is located within the 510 days backward time period, with lower values between 0 and 5 days, indicating a longer time since the air had left the stratosphere.

The very low RH values in Fig. 8 indicate some significant overestimation of mixing in the model (or a lack of vertical resolution) due to the narrow vertical width of the layer. The $\mathrm{RH}$ results demonstrate that strong decrease of the ozone values in the very thin upper part cannot be explained by mixing during the long travel alone ( 3 to 4 days) from the region around Spitsbergen to the Alps. The difference in mixing ratio is more likely caused by the details of the air mass export from the stratosphere at high latitudes.

\subsection{2 to 23 January 2009}

A second spectacular case, for which extended simultaneous lidar series of both ozone and water vapour were achieved, occurred on 22 and 23 January 2009 (see Fig. 11 for ozone, Fig. 12 for selected ozone and water-vapour profiles). On these 2 days, again, an intrusion system descended all the 


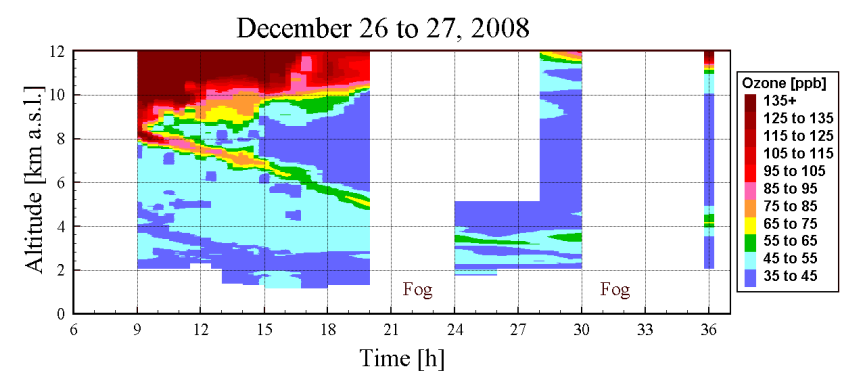

Figure 6. Time series of ozone from lidar measurements on 26 and 27 December 2008, showing a very thin stratospheric air intrusion descending from the tropopause to almost $3 \mathrm{~km}$ a.s.l.; after the descent the intrusion seems to climb again to more than $4 \mathrm{~km}$.

way from just below the tropopause down to the Alpine summit levels (marked by the labels L1 and L2 in Fig. 11). This intrusion system was accompanied by a second layer of elevated ozone (marked by L3 and L4) that stayed at rather constant altitude, first just slightly above and later around the Zugspitze summit (Zugspitze data: Fig. 13). A third highlight of this case is that, despite a much longer advection time, considerable dryness was, again, observed.

In Fig. 12 we give two $\mathrm{H}_{2} \mathrm{O}$ density profiles from two relevant time periods, together with ozone profiles from almost simultaneous measurements. In both intrusions, again, the water-vapour density was very low. For the narrow lower layer (labelled as L3, L4) the values were particularly small between 14:30 and 18:20 CET on 22 January, with an average of $2.2 \times 10^{-20} \mathrm{~m}^{-3}$ and a standard deviation of $4.2 \times$ $10^{-20} \mathrm{~m}^{-3}$. For comparison, $1 \% \mathrm{RH}$, calculated from the temperature data of the Munich radiosonde, corresponds to an $\mathrm{H}_{2} \mathrm{O}$ density of $7 \times 10^{-20} \mathrm{~m}^{-3}$ at $3200 \mathrm{~m}$.

Despite the lower-stratospheric humidity level the ozone values in the lower intrusion layer, with one exception at 21:00 CET, stayed below $70 \mathrm{ppb}$. The extreme dryness demonstrates that the moderate ozone cannot be explained by mixing of the stratospheric layer with the surrounding tropospheric air.

Although the time series in Fig. 11 looks coherently structured this event was rather complex and related to longer advection starting over Canada (Figs. 14 and 15). Again, filamentation is observed and the different elevated-ozone segments are due to the passage of different filaments or combinations of filaments. Since the main focus of this paper is on the humidity results the interpretation of the intrusion layers of L1-L4 is simplified and shifted to the following section.

\subsubsection{Brief analysis}

The LAGRANTO trajectory images in Figs. 14 and 15 yield some information for understanding the observations shown in Fig. 11. For STT trajectories initialized early (e.g. 18 January, 00:00 UTC, not shown) there are two broad bands of STT trajectories (named S1 and S2) originating over Québec

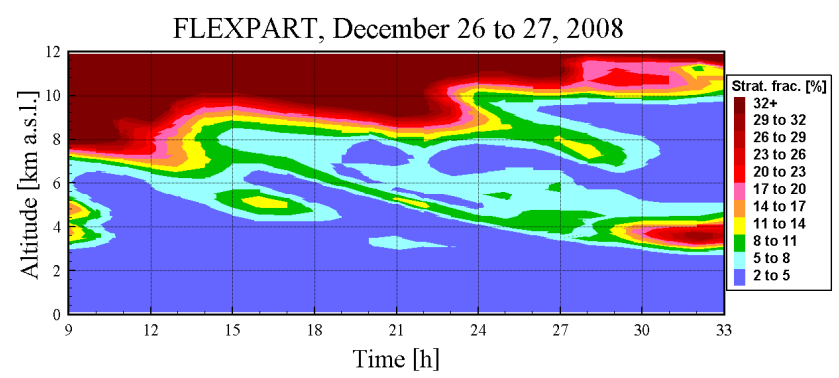

Figure 7. FLEXPART stratospheric fractions for the period shown in Fig. 8, obtained from 20-day retroplume calculations; the average fractions for the first 5 backward days are taken.

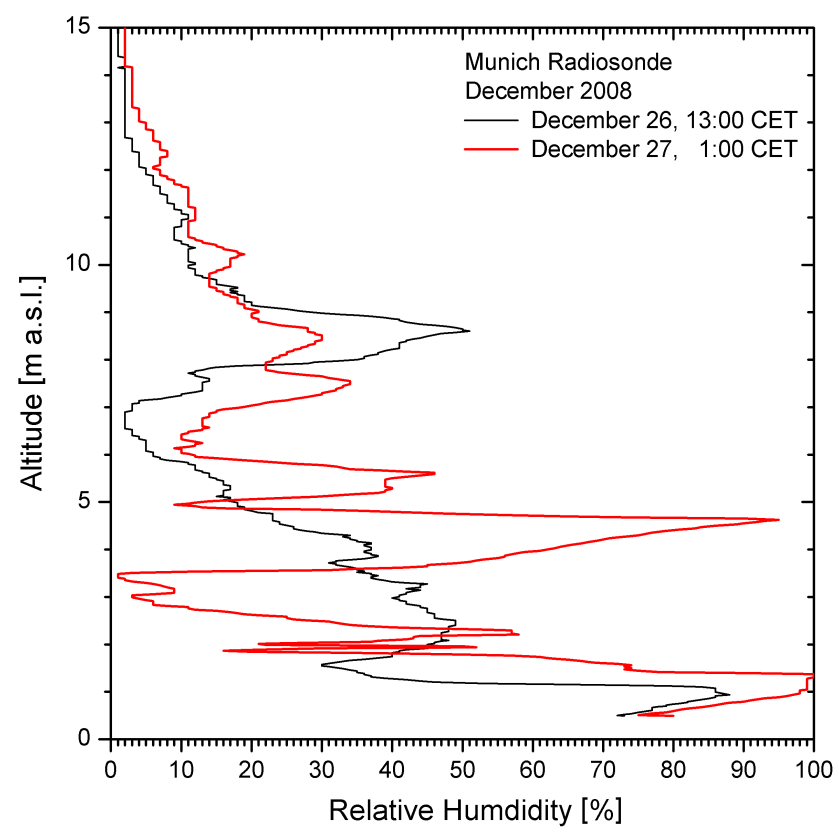

Figure 8. RH profiles of the Munich radiosonde on 26 and $27 \mathrm{De}-$ cember 2008 (source: German Weather Service); the intrusion layer is seen at $6.7 \mathrm{~km}$ (26 December, 13:00 CET) and at $3.4 \mathrm{~km}(27 \mathrm{De}-$ cember, 1:00 CET). Note that the sonde data are cut off at $1 \% \mathrm{RH}$. Thermal tropopause: 11.3 and $10.2 \mathrm{~km}$, respectively.

and Labrador, respectively, approaching Europe parallel on straight pathways. S1 faded away within less than 1 day, but is still visible for 18 January, 12:00 UTC (Fig. 14).

During the final part of the approach parts of both intrusions curl off and lead to the formation of a number of filaments that change with time. Four different filaments create the pattern of Fig. 11 and define the different layers marked as L1 to L4:

1. Intrusion layer L3 is related to a filament arriving above Garmisch-Partenkirchen from the southwest (Spain) at low altitudes (Fig. 14). This filament, interestingly, contains components from both S1 and S2. The travel time of these components was roughly 4 days. 


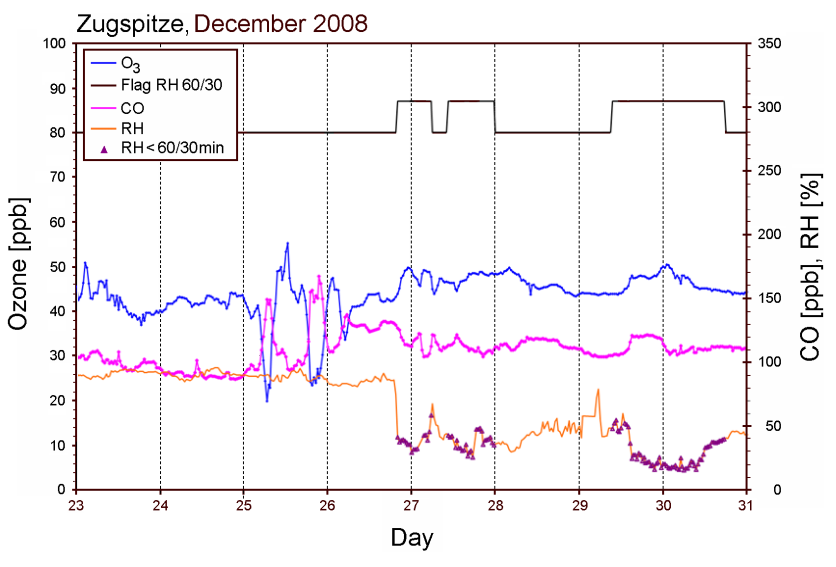

Figure 9. Zugspitze data around 26 December 2008; during the intrusion period on late 26 December and on 27 December only a slight anti-correlation of ozone and carbon monoxide is seen.

2. Layer L4 corresponds to a direct descent further north within $\mathrm{S} 2$, as verified by backward trajectories calculated with the HYSPLIT model (Draxler and Hess, 1998; http://ready.arl.noaa.gov/HYSPLIT traj.php, travel time from the southern tip of Greenland: 4 to 5 days).

3. Layer L1 stays at rather high altitudes, and this is also the case for the corresponding trajectory bundle identified in Fig. 15. Layer L1 emerged from a later phase of intrusion S2 and proceeded to Southern Spain and Northern Morocco before turning towards Central Europe and farther to the northeast. GarmischPartenkirchen is slightly missed by this bundle. This could be due to uncertainties in the trajectory analysis. However, we believe that, due to a missing pronounced descent, some trajectories could have been missed by the ETH pressure-difference criterion used for identifying strong descent. This view is confirmed by HYSPLIT backward trajectories calculated for Layer L1: they run parallel to the branch in Fig. 15 marked by L1 and reveal an air mass descent from about $11 \mathrm{~km}$ slightly south of Greenland.

4. Layer L2 is deceiving since the almost straight descent of the high-ozone layer in Fig. 11 looks almost continuous. Both the LAGRANTO and the HYSPLIT analyses show that two different pathways are involved. In Fig. 15 we label the trajectory bundle that corresponds to layer L2. Within the following $6 \mathrm{~h}$ it shifted westward and exactly passed over Garmisch-Partenkirchen in the 00:00 UTC (01:00 CET) LAGRANTO trajectory plot at altitudes agreeing with those observed.

\subsection{How dry are stratospheric air intrusions?}

In 2004 and between 2007 and June 2013 very dry air layers descending to $5.5 \mathrm{~km}$ and less are observed with the Zugspitze water-vapour DIAL on a total of 80 days. This is roughly one quarter of the full number of measurement days and, again (Trickl et al., 2010), demonstrates the significance of deep downward transport of lower-stratospheric air for the ozone budget at high peaks of the Alps. On 8 of these days there is some uncertainty about the stratospheric nature of the air mass due to unclear trajectory results or the absence of a pronounced ozone peak in the corresponding measurements with the ozone DIAL.

A selection of these cases is listed in Table 1. To compare these cases with the Zugspitze summit station only intrusions with centres subsiding to at least $3.6 \mathrm{~km}$ a.s.l. during a specific measurement period are included. The maximum uncertainty of the values in intrusion layers derived from the DIAL measurements around $3 \mathrm{~km}$ is of the order of $\pm 5 \times 10^{-20} \mathrm{~m}^{-3}, \pm 25 \mathrm{ppm}$ or $\pm 0.5 \% \mathrm{RH}$ (Sect. 3.1), unless there is detector overload caused by particles or snow from the adjacent slopes blown through the laser beam. RH data gaps caused by a computer failure or the death of co-author H.-E. Scheel were filled by values from the German Weather Service (Deutscher Wetterdienst, DWD) registered at the adjacent DWD Zugspitze summit station.

We also give the intrusion types as defined by source region and pathway by Trickl et al. (2010) and crude estimates of the transport time determined from trajectories. The shortest travel times are associated with Type-1 intrusions that anticyclonically approach from the region around Greenland to Central Europe. For these cases normally very low watervapour densities are registered. Type 2 corresponds to the same source region, but with cyclonic approach to GarmischPartenkirchen. In many cases longer transport times occur, in particular if the intrusion propagates far south along the west coast of Europe before some of the air mass returns towards the Alps. Formation of large-scale loops in the advection pathway has also been observed for Type 2, e.g. on 11 November 2004 and 25 April 2013. For longer advection (Type 5: from Eastern Canada; Type 6: from Canada west of $80^{\circ} \mathrm{W}$ or even more remote regions, identified by HYSPLIT calculations) the humidity values in the intrusion layers vary even more.

The full statistics on the deep stratospheric intrusions registered with the water-vapour DIAL are shown by the histograms in Fig. 16. In the figure we just focus on the volume mixing ratio which is the most important quantity for judging the modification of the dry layers on the way downward from the tropopause region. The panels are given for different ranges of travel times estimated from the LAGRANTO and the HYSPLIT trajectories. For the longer travel times the width of the distribution grows in agreement with the idea of increasing tropospheric contributions in these layers. There is some indication of a bimodal behaviour for the longest 


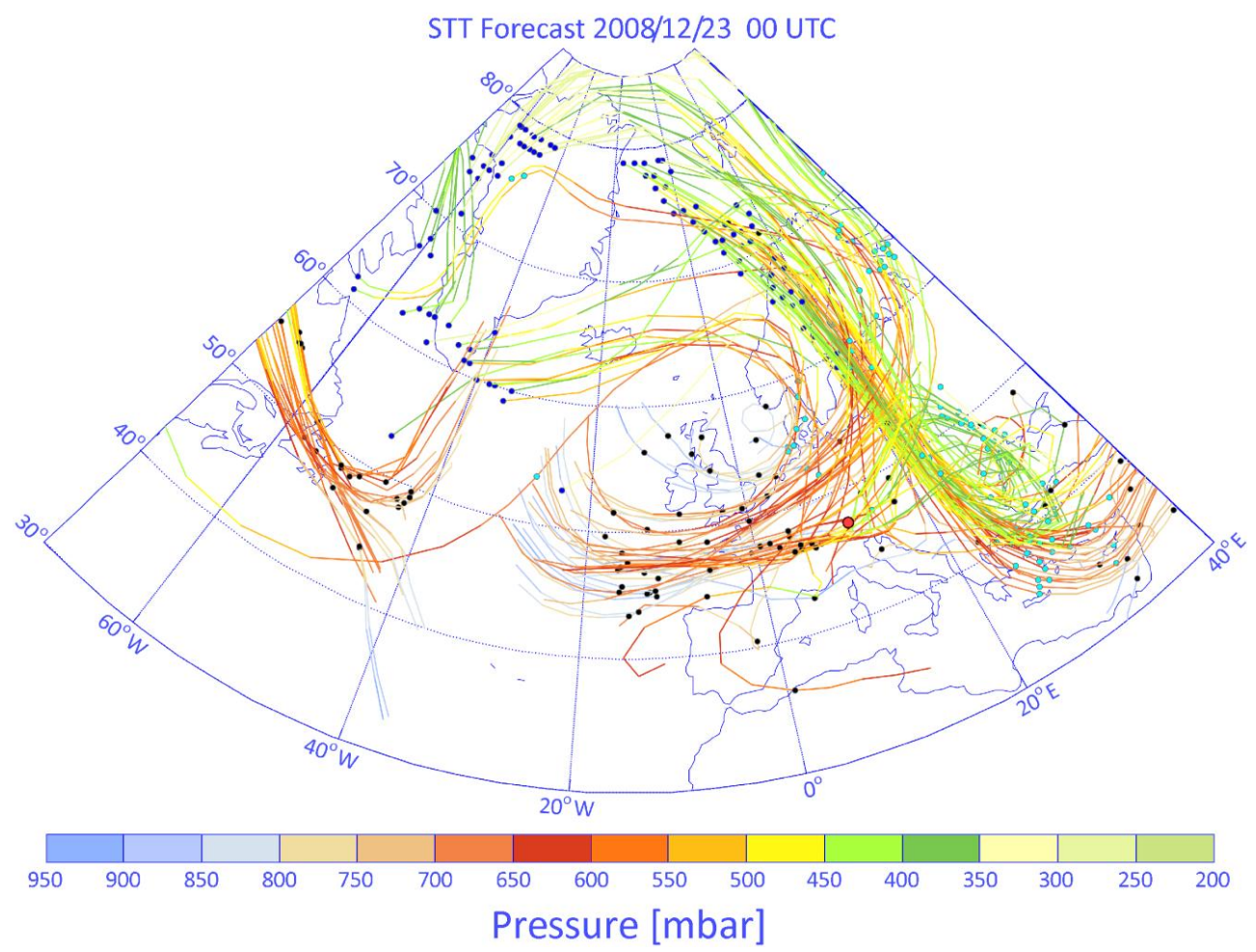

Figure 10. The 5-day LAGRANTO intrusion trajectories, based on ECMWF re-analysis data: the trajectories were initiated on 23 December 2008, at $t_{\mathrm{O}}=00: 00 \mathrm{UTC}(01: 00 \mathrm{CET})$. The time positions on the trajectories for $t_{\mathrm{O}}, t_{\mathrm{O}}+2$ days and $t_{\mathrm{O}}+4$ days are marked by dark blue, light blue and black dots, respectively. The position of Garmisch-Partenkirchen is marked by a red dot. It is reached during the observational period.

travel times, with a very dry component still being observable. This suggests that the air mass can stay more or less unchanged for 1-2 weeks (the time of descent in the HYSPLIT results) in a significant number of cases. In the other cases we hypothesize a growing probability of entrainment of moist tropospheric air. Such entrainment can occur both by convection or turbulence driven by strong vertical wind shear.

Table 2 lists the average values and standard deviations of different types of humidity for the three ranges of travel times specified in Fig. 16. Most importantly, the average mixing ratio for the direct intrusions associated with short travel times stays below typical upper-tropospheric values of the order of $100 \mathrm{ppm}$ that we derived from radiosonde data (see also below). If we exclude the seven values exceeding $100 \mathrm{ppm}$ the average and the standard deviation become as low as 14 and $28 \mathrm{ppm}$, respectively. This standard deviation agrees with our error estimate for the DIAL measurements. For RH, a slightly larger standard deviation of $1.1 \%$ is obtained due to the extended altitude range of this assessment.

Shapiro (1980) suggested a $50 \%$ mixture of stratospheric and tropospheric air in intrusion layers after the phase of strongest turbulent mixing. In order to compare our results with this fraction we averaged the water-vapour mixing ratios from the radiosonde data for the station Narsarsuaq in southern Greenland (representing the most typical source region) in the uppermost 0.5 to $1.0 \mathrm{~km}$ of the troposphere. We selected the months March and July 2008 to represent two different seasons. The average mixing ratios are $85 \mathrm{ppm}$ during both months, but the standard deviations, 62 and $31 \mathrm{ppm}$, respectively, differ strongly. Also the vertical variability of the thermal tropopause above Narsarsuaq is substantially stronger in March (roughly 5 to $10 \mathrm{~km}$ ) than in July (9 to $11 \mathrm{~km})$.

The $50 \%$ mixing, as estimated by Shapiro, corresponds to an average of the stratospheric mixing ratio of $5 \mathrm{ppm}$ and the above monthly average, i.e. $45 \mathrm{ppm}$. This agrees well with the average of the minimum values listed in Table 2 for travel times up to 3 days. On the other hand, the conservation of the mixing ratio during the travel of the air mass to the Alps would suggest low additional mixing of an intrusion layer after penetrating deeper into the troposphere. It is difficult to understand why mixing would stop abruptly as the air descends. In addition, the high number of even drier cases observed by us challenges the $50 \%$ fraction of tropospheric air in the literature. These issues are discussed in Sect. 5.

From the large number of comparisons between lidar and station we can conclude that there is an obvious wet bias of the order of $10 \% \mathrm{RH}$ in the Zugspitze station data (Table 1). Of course, RH values significantly exceeding $10 \%$ are also 


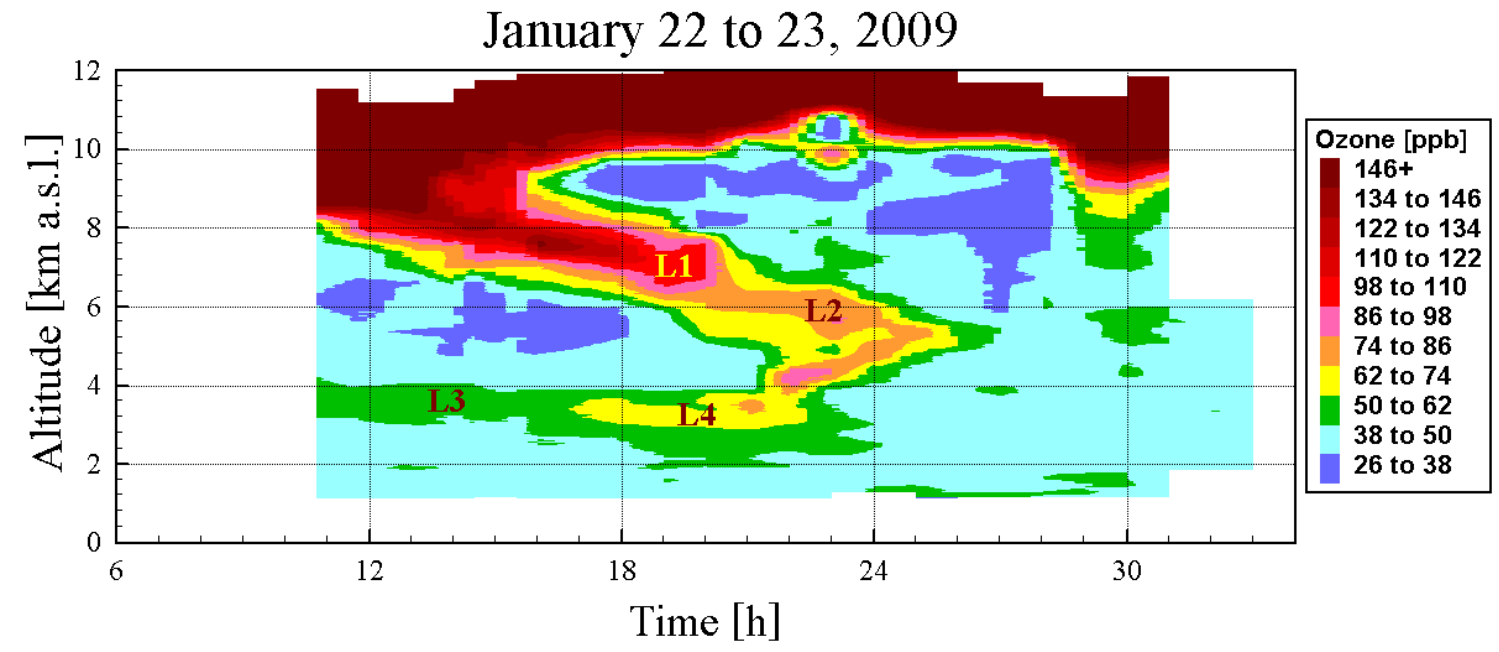

Figure 11. Ozone soundings on 22 and 23 January 2009; four intrusion layers (L1, L2, L3, L4) are identified, corresponding to different advection pathways (see text).

Table 1. List of minimum humidity values (volume mixing ratio, VMR, and RH) in stratospheric air intrusions detected with the watervapour DIAL; only intrusions that descended to $3.6 \mathrm{~km}$ and less and (with one exception) observed at the Zugspitze summit were included; the values are compared with minimum-RH data from the Munich or Stuttgart radiosonde (RHS; AltS: layer altitude in sonde measurement) and the Zugspitze summit station (RHZ; in italics: from DWD). The intrusion types are listed as defined by Trickl et al. (2010). The crude travel time (TT) is estimated from the trajectory results. OZ: measurement(s) of ozone DIAL available; AltM: altitude of sonde minimum RH.

\begin{tabular}{|c|c|c|c|c|c|c|c|c|c|c|}
\hline Date & $\begin{array}{r}\text { Time } \\
{[\mathrm{CET}]}\end{array}$ & $\begin{array}{r}\text { Altitude } \\
{[\mathrm{km}]}\end{array}$ & $\begin{array}{r}\text { Min. VMR } \\
{[\mathrm{ppm}]}\end{array}$ & $\begin{array}{r}\text { Min. } \mathrm{RH} \\
{[\%]}\end{array}$ & $\begin{array}{l}\text { Intr. } \\
\text { type }\end{array}$ & $\begin{array}{r}\mathrm{TT} \\
\text { [day] }\end{array}$ & $\begin{array}{r}\mathrm{OZ} \\
{[\%]}\end{array}$ & $\begin{array}{l}\text { RHS } \\
{[\mathrm{km}]}\end{array}$ & $\begin{array}{r}\text { AltS } \\
{[\%]}\end{array}$ & RHZ \\
\hline 12 Mar 2007 & $22: 25$ & 2.9 & 0.0 & 0.0 & 3 & 2 & No & 5 & 2.7 & 7.7 \\
\hline 5 Apr 2007 & $12: 08$ & 3.0 & 130.0 & 1.8 & 1 & 2 & Yes & 4 & 3.8 & 10.0 \\
\hline 19 Apr 2007 & $12: 01$ & 3.1 & 0.0 & 0.0 & 1 & 3 & Yes & 2 & 3.4 & 7.6 \\
\hline 11 Oct 2007 & $14: 12$ & 3.3 & 36.4 & 0.4 & 1 & 4 & Yes & 5 & 2.7 & 14.5 \\
\hline 31 Oct 2007 & $12: 39$ & 3.3 & -27.2 & -0.4 & 1 & 2 & No & 2 & 3.3 & 14.0 \\
\hline 13 Dec 2007 & $19: 14$ & 3.0 & 24.4 & 0.6 & 1 & 2 & No & 2 & 3.8 & 9.4 \\
\hline 14 Dec 2007 & $16: 15$ & 3.2 & 11.6 & 0.4 & 1 & 4 & No & 1 & 3.3 & 17.0 \\
\hline 11 Feb 2008 & $11: 22$ & 2.9 & 0.0 & 0.0 & 4 & 4 & No & 2 & 3.3 & 9.8 \\
\hline 6 Mar 2008 & $11: 18$ & 3.0 & 0.0 & 0.0 & 1 & $3.5-4$ & Yes & 1 & 3.6 & 14.5 \\
\hline 19 Mar 2008 & $09: 53$ & 3.1 & 53.0 & 1.0 & 1 & $2-4$ & No & (17) & 3.2 & $(28.0)$ \\
\hline 17 Oct 2008 & 20:09 & 3.2 & -27.3 & -0.3 & 1 & 2 & No & 1 & 2.8 & 6.2 \\
\hline 22 Jan 2009 & $16: 49$ & 3.1 & -15.9 & -0.4 & 5 & 4 & Yes & 4 & 2.9 & 10.6 \\
\hline 16 Mar 2009 & $13: 58$ & 3.4 & 124.8 & 2.2 & 1 & 3.5 & No & 2 & 5.1 & $(23.1)$ \\
\hline 27 Oct 2009 & $12: 54$ & 3.6 & -28.4 & -0.4 & 4 & 1.5 & Yes & 3 & 3.7 & 9.5 \\
\hline 8 Mar 2010 & $12: 58$ & 3.4 & 68.2 & 4.8 & 1 & $2-4$ & No & 4 & 3.4 & $22 D W D$ \\
\hline 17 Mar 2010 & $16: 10$ & 3.3 & -26.8 & -0.6 & $6^{\mathrm{a}}$ & $>11$ & No & 3 & 3.2 & $21 \mathrm{DWD}$ \\
\hline 4 Oct 2011 & $10: 28$ & 3.0 & 1.8 & 0.0 & 2 & 3 & No & 5 & 3.9 & $9 D W D$ \\
\hline 24 Nov 2011 & $10: 18$ & 3.3 & 162.1 & 2.5 & 5 & 4 & Yes & 5 & 4.2 & $3 D W D$ \\
\hline 12 Jan 2012 & $16: 06$ & 3.3 & 3.6 & 0.1 & $6^{\mathrm{a}}$ & $\geq 11$ & No & 6 & 3.2 & $23 D W D$ \\
\hline 8 Aug 2012 & $08: 12$ & 3.1 & -15.8 & -0.2 & $6^{\mathrm{a}}$ & $\geq 13$ & No & 7 & 4.0 & $29 D W D$ \\
\hline 8 Oct 2012 & $09: 42$ & 3.0 & 0.0 & 0.0 & 2 & $2-4$ & No & 1 & 3.0 & $8 D W D$ \\
\hline 13 Feb 2013 & $12: 31$ & 3.1 & 15.2 & 0.6 & 1 & 2 & No & 5 & 4.0 & n.a. \\
\hline Mean $^{b}$ & & & 22.3 & 0.55 & & & & 3.3 & & 10.9 \\
\hline \multicolumn{3}{|c|}{ Standard deviation ${ }^{b}$} & 54.0 & 1.27 & & & & 1.8 & & 3.3 \\
\hline
\end{tabular}

${ }^{a}$ From HYSPLIT run.

${ }^{\mathrm{b}}$ Calculated without values in brackets and without RH values from the German Weather Service (Deutscher Wetterdienst, DWD). 
Table 2. Minimum humidity values in stratospheric intrusion layers as observed with the Zugspitze DIAL in the altitude range between 2.9 and $3.6 \mathrm{~km}$ (in 2004 and from 2007 to June 2013) for different travel times from the stratosphere to Garmisch-Partenkirchen.

\begin{tabular}{lcc}
\hline Travel time & Mean value & Standard deviation \\
\hline (a) Number density & \\
\hline 1 to 3 days: & $8.7 \times 10^{20} \mathrm{~m}^{-3}$ & $1.3 \times 10^{21} \mathrm{~m}^{-3}$ \\
4 to 6 days: & $2.1 \times 10^{21} \mathrm{~m}^{-3}$ & $2.9 \times 10^{21} \mathrm{~m}^{-3}$ \\
$>6$ days: & $3.9 \times 10^{21} \mathrm{~m}^{-3}$ & $4.4 \times 10^{21} \mathrm{~m}^{-3}$ \\
\hline (b) Mixing ratio & \\
\hline 1 to 3 days: & $49 \mathrm{ppm}$ & $73 \mathrm{ppm}$ \\
4 to 6 days: & $121 \mathrm{ppm}$ & $164 \mathrm{ppm}$ \\
$>6$ days: & $222 \mathrm{ppm}$ & $247 \mathrm{ppm}$ \\
\hline (c) Relative humidity & \\
\hline 1 to 3 days: & $1.1 \%$ & $1.5 \%$ \\
4 to 6 days: & $2.1 \%$ & $3.6 \%$ \\
$>6$ days: & $3.5 \%$ & $3.3 \%$ \\
\hline
\end{tabular}

observed at the station due to the delay with respect to the lidar (change in air mass) or insufficient overlap with the dry layer. In rare cases RH values in the range down to about $3 \%$ have been seen in the past. We tentatively ascribe this wet bias to insufficient cooling of the dewpoint mirror. The DWD RH data also exhibit this wet bias in the dry layers. A comparison for an extended period showed reasonable agreement between the two instruments within intrusions, although the Weather Service uses Vaisala HMP45D sensors instead of a dewpoint mirror. This is due to the calibration procedure applied.

We can clearly exclude that orographic effects (Carnuth and Trickl, 2000; Carnuth et al., 2002) influence the minimum values of the in situ sensors. Daytime slope winds lift moister air from lower altitudes to the summit station during the warm season, which then results in positive deviations from the DIAL humidity that is measured outside the shallow slope-wind layer (Vogelmann and Trickl, 2008). However, the wet bias of the in situ measurements is also present in winter or during night-time when orographic upward transport does not take place and when there is no evaporation from wet surfaces. In addition, during periods of subsidence the orographic influence is usually suppressed.

There is much better agreement of the lidar and the radiosonde data. Despite the considerable distance between the two measurement sites of about $100 \mathrm{~km}$, the agreement with the radiosonde data for Oberschleißheim ("Munich"; in a few cases the Stuttgart results had to be taken due to missing data) within intrusions is reasonable (see Vogelmann and Trickl, 2008 for an example). The soundings are based on RS 92 sondes at least after August 2005 (Steinbrecht et al., 2008) that are obviously capable of repro-

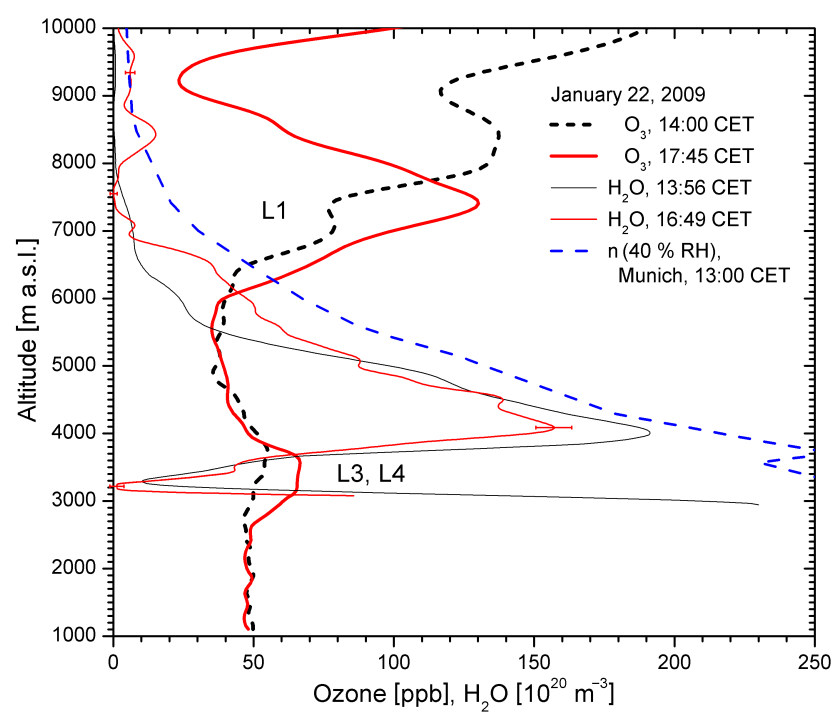

Figure 12. Two selected water-vapour density profiles from the single-day time series that ended shortly before 21:00 CET. The corresponding ozone profiles are given for comparison. The labels L1, L3 and L4 correspond to those in Fig. 11. The dryness of the intrusion layers is further visualized by adding the number density corresponding to $40 \% \mathrm{RH}$, calculated from the Munich 13:00 CET temperature profile.

ducing the low humidity levels in these air streams. The data inserted into Table 1 were downloaded from the web site http://weather.uwyo.edu/upperair/sounding.html and, as mentioned, seem to be artificially cut off at a minimum of $1 \%$ RH. For the case studies in Sects. 4.1-4.3 we obtained vertically better-resolved data from the German Weather Service.

In summary, we conclude that the nature of intrusion layers is far more stratospheric than indicated by the dewpoint mirror instrument at the summit station. In the majority of cases the minimum water-vapour mixing ratio in intrusions that descended to at least $3.6 \mathrm{~km}$ is substantially lower than typical upper-tropospheric values.

\subsection{Trend of Zugspitze carbon monoxide 1990-2004}

It is an interesting fact that Zugspitze carbon monoxide in stratospheric air intrusions never drops to stratospheric values. As mentioned in Sect. 4.1, 20 to $40 \mathrm{ppb}$ of CO are expected for fully stratospheric air, but the multiple research flights (see Introduction) have found strong evidence of higher values in a "mixing layer" in the tropopause region. We conclude that the intrusions observed at the Zugspitze summit originate in the lowest few kilometres of the stratosphere, with unknown upper-tropospheric admixtures.

Figure 17 indicates a positive trend for $\mathrm{CO}$ in intrusion layers whereas for non-intrusion layers the trend is opposite. This suggests that the lowermost high-latitude stratosphere as the typical source of the intrusions observed at our 


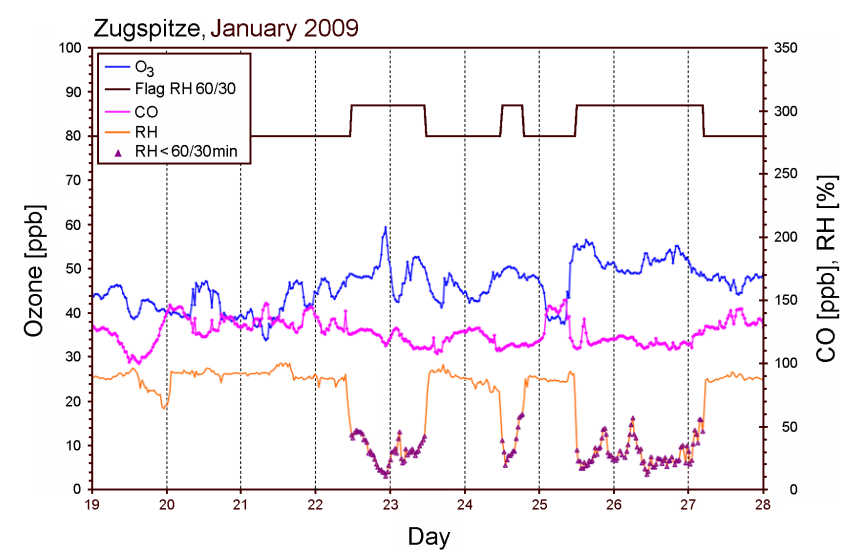

Figure 13. Zugspitze data around 22 January 2009; the maximum of intrusion layer L4 is visible during the final hours of 22 January. CO drops by only $10 \mathrm{ppb}$ during that period.

measurement site is influenced by upward transport of air from regions with growing air pollution, namely in East Asia (see Sect. 5). The downward trend for the complementary air masses reflects import predominately from Europe or other regions such as North America with diminishing air pollution during that period.

The results in Fig. 17 were taken as prepared for the ATMOFAST final report (ATMOFAST, 2005). They are based on data selection using the restrictive traditional criterion ${ }^{7} \mathrm{Be}<85$ th percentile (Scheel, 2002, 2003), that approximately corresponds to the classical $8 \mathrm{mBq} \mathrm{m}^{-3}$ threshold (Sladkovic and Munzert, 1990; Stohl et al., 2000), and $\mathrm{RH}<60 \%$. This criterion covers roughly one half of the intrusion cases hitting the Zugspitze summit (Trickl et al., 2010). Some revision of the results based on our new data filtering strategies (Trickl et al., 2010) is planned, but is currently postponed due to the unexpected death of our coauthor H.-E. Scheel.

\section{Discussion and conclusions}

The results so far obtained for deep stratospheric air intrusions reaching the Garmisch-Partenkirchen area suggest that very little mixing occurs within most of the troposphere and that it is limited to the layer boundaries, without touching the very dry layer cores (Sect. 4.4). In $63 \%$ of the deep intrusion cases corresponding to the lowest panel of Fig. 16 the minimum mixing ratio stays below $50 \mathrm{ppm}$ (in 17 cases even less than $30 \mathrm{ppm}$ ), with an average of less than $15 \mathrm{ppm}$. Intrusions directly travelling from the Arctic source regions to the Alps arrive within typically 2 days after departure. Di Girolamo et al. (2009) report $\mathrm{RH}=0.2 \%$ between 2 and $4 \mathrm{~km}$ even $950 \mathrm{~km}$ farther downstream in a Type- 1 intrusion departing from southern Greenland, as identified by our forecast plots. There is evidence of negligible or very small air mass modification for even much longer free-tropospheric transport (Table 1 and an unpublished example of long-range transport over more than twenty days; see also Bithell et al., 2000). These observations demonstrate that without strong wind shear or convective processes free-tropospheric mixing is much slower than anticipated from earlier work. The examples shown here demonstrate that this is even the case when the intrusion air mass is split into separate thin filaments. In the March 2008 case very high ozone values were observed at altitudes as low as $3 \mathrm{~km}$, but this is quite exceptional.

Our findings imply a challenge to atmospheric modelling. In addition to the resolution issue for reproducing stratospheric intrusion in models (e.g. Roelofs et al., 2003; Trickl et al., 2010) the resolution of the underlying meteorological data field and the parameterization of free-tropospheric mixing currently impose limitations. Pisso et al. (2009) reconstructed the observations of a Canadian fire plume over the Atlantic in a diffusive Lagrangian approach. The diffusion coefficients for reproducing the airborne measurements were ten times smaller than those in an also used moderateresolution Eulerian model.

By contrast, the results by Shapiro (1976, 1978, 1980; see Sect. 2) suggest significant turbulent mixing in intrusion layers observed in the upper troposphere. However, Shapiro does not address the question of how much of the "tropospheric" component was already present before the air mass reached the region where he determined turbulent exchange.

Our ozone observations, at a first glance, seem to show a picture differing from that derived from the water-vapour results. The lowest portions of the intrusions reaching the Alps do not carry stratospheric amounts of $\mathrm{O}_{3}$, typically just 60 to $80 \mathrm{ppb}$. An explanation of the low ozone values by mixing is now challenged by the very low level of water vapour sometimes even in very thin layers. In a number of cases in our record the descending ozone peaks have exhibited rather sharp edges almost not softened by turbulent exchange. Spatial divergence of the intrusion layers cannot serve as a general explanation of the moderate peak ozone values since quite frequently the trajectory bundles stay almost parallel on the way from, e.g., Greenland to the Alps, the layers exhibiting some tendency of becoming vertically thinner during the descent.

The parts of Type-1 STT layers passing at higher altitudes carry ozone at significantly higher concentrations (e.g. Figs. 6 and 11; Stohl and Trickl, 1999; Zanis et al., 2003). Based on our water-vapour results we hypothesize that the east-west drop in ozone in the typical intrusion layers could to a major extent be caused by the way the layer separates from the tropopause (see also the $\mathrm{O}_{3}-\mathrm{H}_{2} \mathrm{O}$ correlation of Pan et al., 2007). This cannot be studied for the examples in this paper since they exhibit filamentation, but we plan to examine more details in the case of a rather homogeneous intrusion layer mapped with both airborne and ground-based water-vapour lidar systems (Wirth et al., 2009) in a forthcoming paper. Observations of folds forming over Garmisch-Partenkirchen have shown ozone layers 


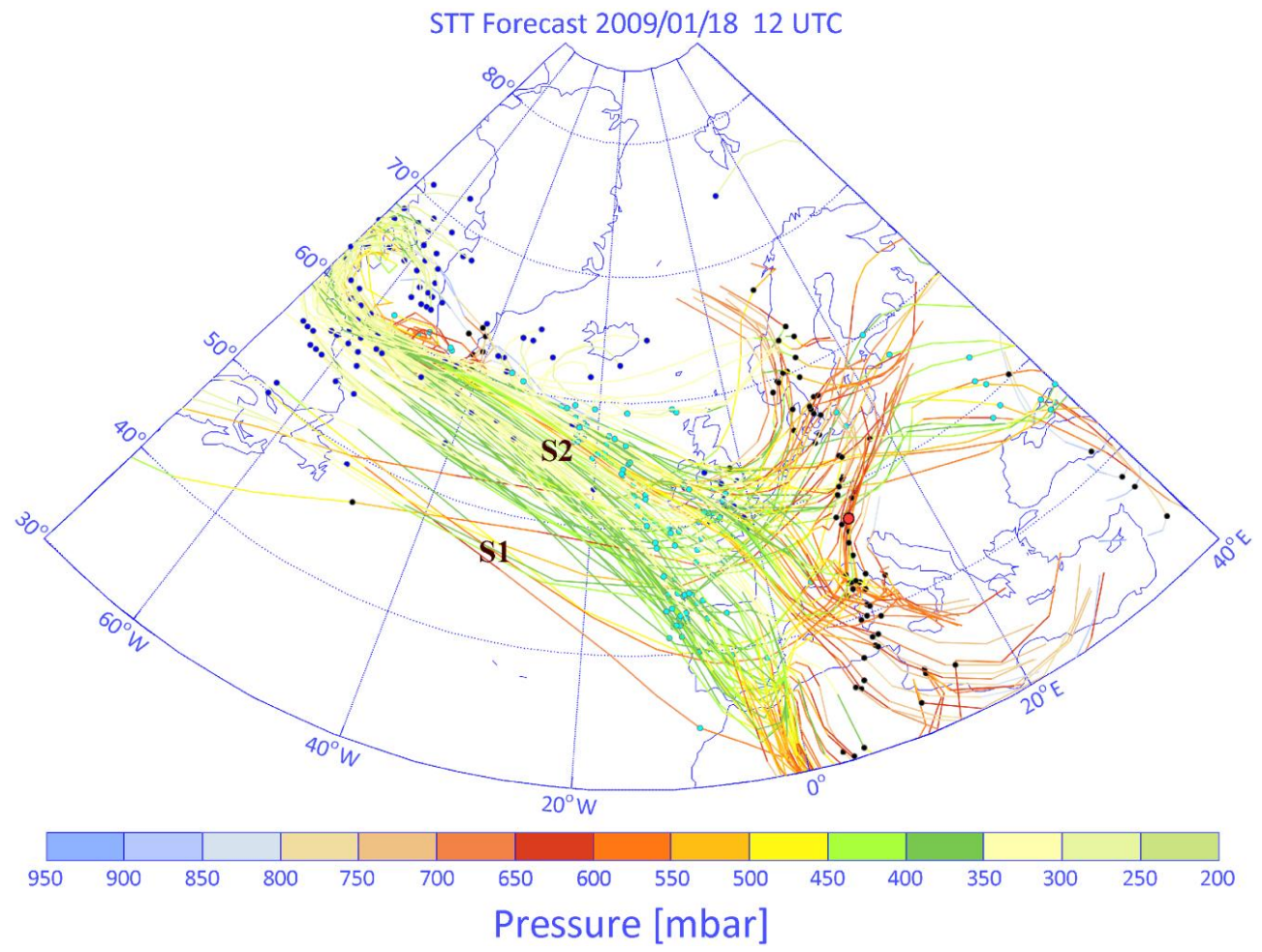

Figure 14. The 5-day LAGRANTO intrusion trajectories, based on ECMWF re-analysis data; the trajectories were initiated on 18 January 2009: at $t_{\mathrm{O}}=00: 00 \mathrm{UTC}(01: 00 \mathrm{CET})$. The time positions on the trajectories for $t_{\mathrm{O}}, t_{\mathrm{O}}+2$ days and $t_{\mathrm{O}}+4$ days are marked by dark blue, light blue and black dots, respectively. Deviating from the operational forecast mode, the full length of the trajectories is 5 days here. The position of Garmisch-Partenkirchen is marked by a red dot. It is reached during the observational period by components from both intrusions, S1 and S2 (Layer L3 in Fig. 11).

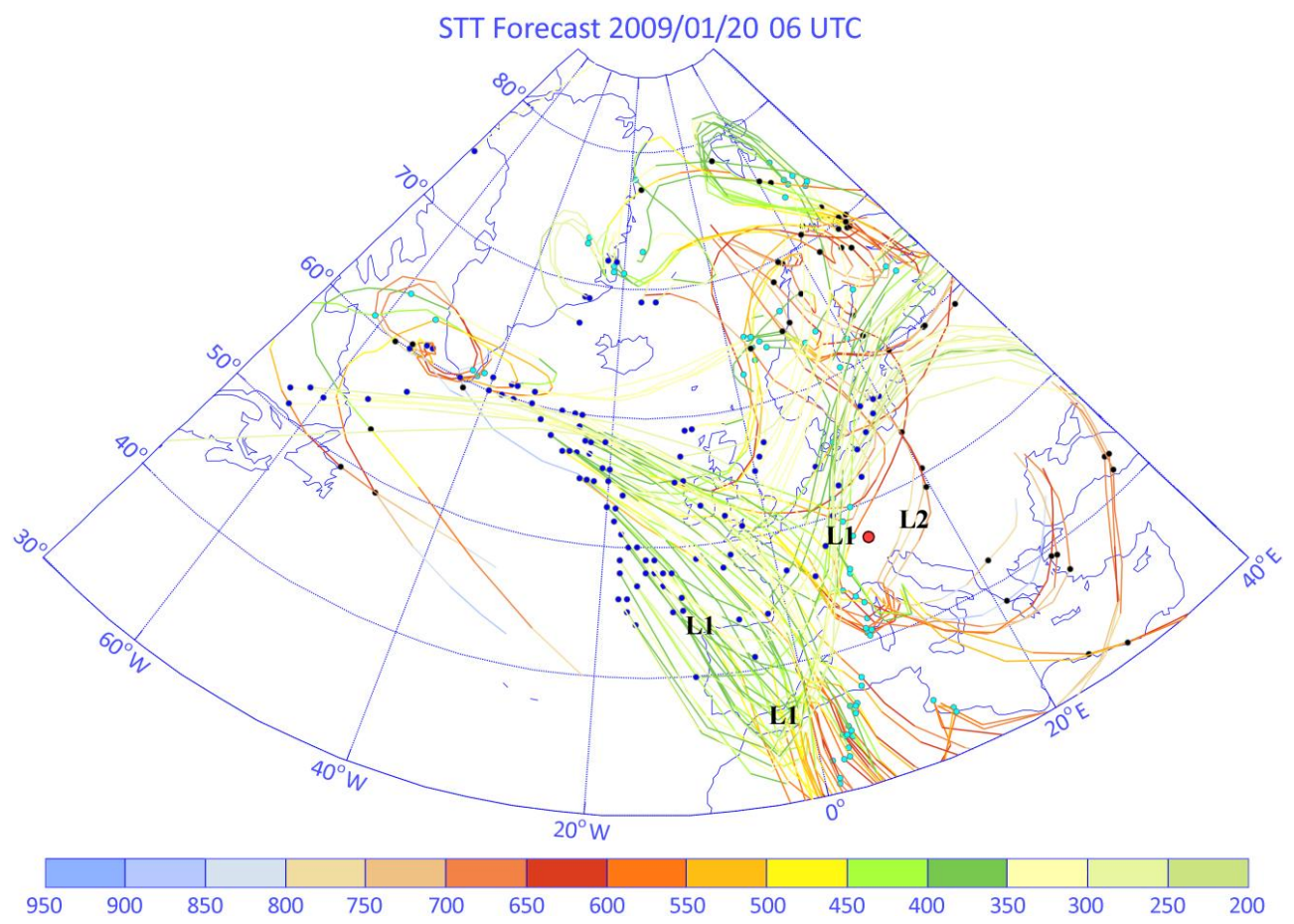

Figure 15. As Fig. 14, but initiated during a later phase of that intrusion, on 20 January 2009, at $t_{\mathrm{o}}=06: 00$ UTC (07:00 CET). Only intrusion $\mathrm{S} 2$ is left. L1 (marked three times during its approach) and L2 correspond to layers shown in Fig. 11 as explained in more detail in the text. 

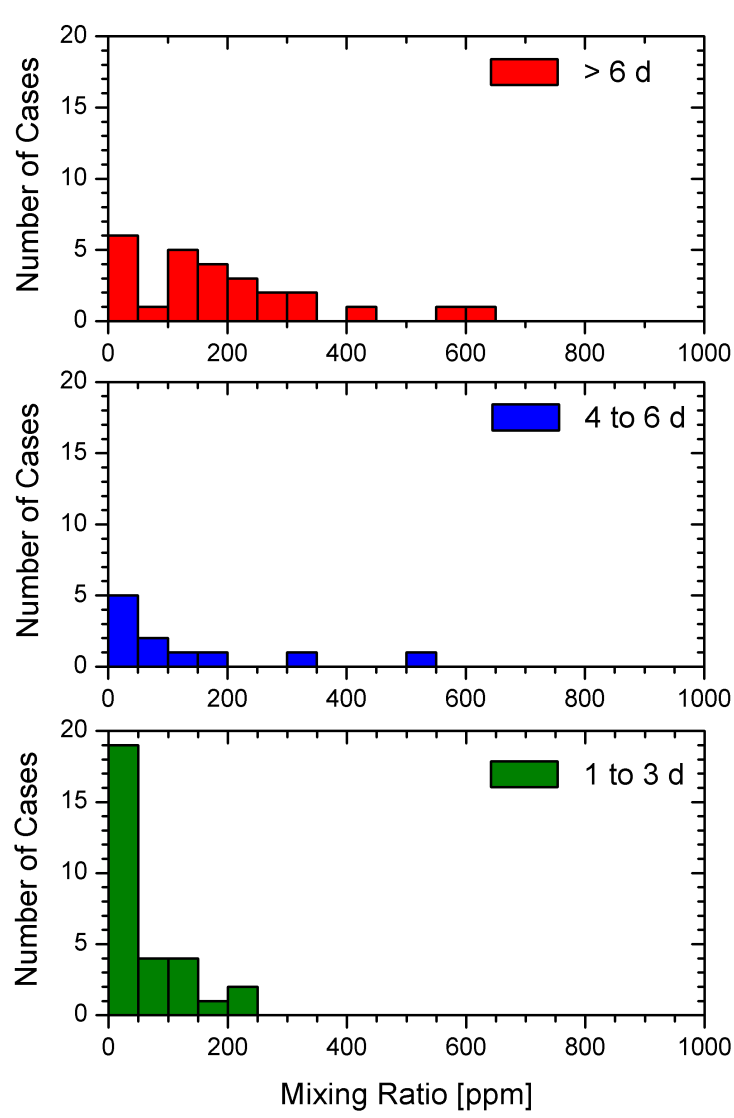

Figure 16. Histograms of the minimum $\mathrm{H}_{2} \mathrm{O}$ volume mixing ratios on days with DIAL observation of a stratospheric air intrusion for three different ranges of air mass travel times; only days with intrusion layers showing humidity minima at $4.5 \mathrm{~km}$ and less have been included.

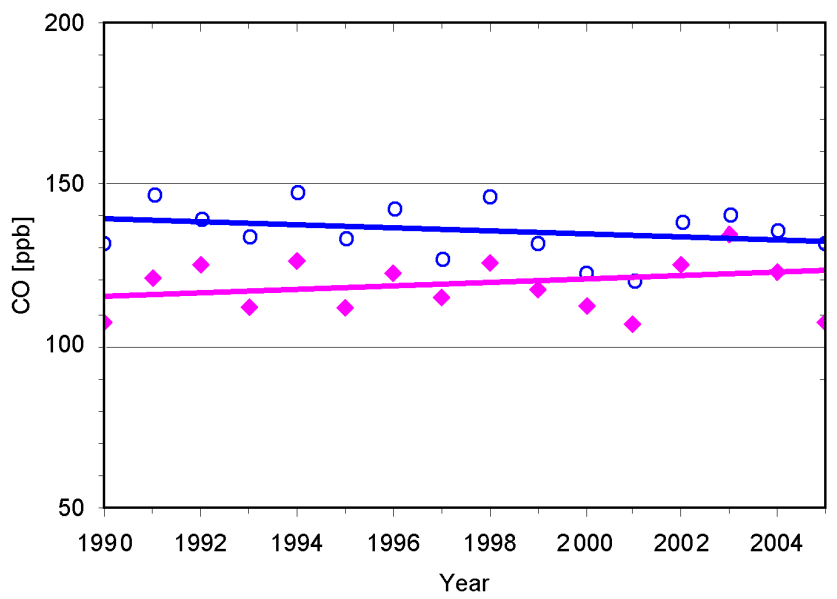

Figure 17. Comparison of the trends for Zugspitze CO based on the annual mean values for all data (upper curve) and the data for periods with stratospheric influence (lower curve).

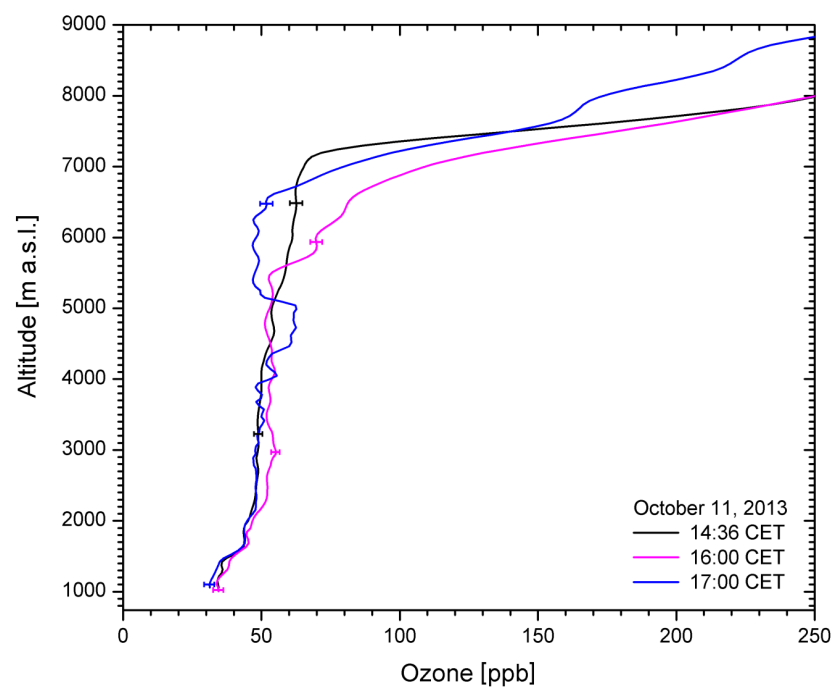

Figure 18. The ozone measurements on 11 October 2013 show a layer with slightly enhanced ozone gradually separating from the tropopause (located at about $7 \mathrm{~km}$ a.s.1.), centred at about $6 \mathrm{~km}$ at 16:00 CET and at $4.75 \mathrm{~km}$ at 17:00 CET. Note the small error bars after recent system upgrading.

separating downward from the tropopause with roughly $150 \mathrm{ppb}$ (Trickl et al., 2010), but also with just about $60 \mathrm{ppb}$, not differing much from the background level (Fig. 18).

Our studies are consistent with an outflow of the intrusion layers from the mixing zone above the dynamical tropopause. Sprung and Zahn (2010) determined an extent of the mixing zone to 3 to $5 \mathrm{~km}$ above the thermal tropopause. The Zugspitze CO results, revealing just a small drop during STT events, indicate that the intrusions mostly do not come from above this layer. Interestingly, Brioude et al. (2006) also reported more than $90 \mathrm{ppb}$ of $\mathrm{CO}$ in a pronounced intrusion layer with almost $120 \mathrm{ppb}$ of ozone observed between 600 and 700 mbar during a descent of a MOZAIC flight into New York (see Danielsen et al., 1987 for another example).

The positive trend of $\mathrm{CO}$ advected to the Zugspitze summit in stratospheric air intrusions has stimulated us to speculate on potential Asian inflow into the lowermost stratosphere over Northern Canada and Greenland, where most intrusions relevant for our area come from. East Asia is the region with the currently most strongly increasing level of air pollution (e.g. Richter et al., 2005). At the same time warm-conveyor-belt activity is high over the Western $\mathrm{Pa}$ cific resulting in considerable lifting of polluted air masses towards the Gulf of Alaska (Stohl, 2001; Stohl et al. al., 2002b, 2003c; Eckhardt, 2004; Cooper, 2004a, b). Roiger et al. (2011) observed an air-pollution plume from China in the lowermost stratosphere over Greenland on 10 July 2008. The Zugspitze data reveal a CO peak towards the end of an intrusion on 16 July 2008. However, trajectory calculations did not yield evidence of matching air masses. 
Trajectory calculations in a case study by Pan et al. (2007) suggest (if transferrable) that Asian emissions do not directly flow into the fold itself, but stay more above the jet core. As a consequence, one would expect more aged $\mathrm{CO}$ contributions in the intrusions, i.e. contributions that have circulated in the polar region for some longer time. This could to some extent explain the rather weak positive trend in the Zugspitze data.

Finally, what are the implications for the quantification of stratospheric ozone reaching the Zugspitze summit? First of all, the measurements with the water-vapour DIAL demonstrate that the wet bias of the dewpoint mirror instrument used is artificial and possibly caused by insufficient cooling of the mirror. Our results imply that the data filtering applied to the Zugspitze data is significantly more realistic than thought. Since the humidity measurements cannot be repeated back to 1978 with a more accurate instrument an estimate of tropospheric contributions to intrusion layers has limitations. Some strategy must be derived for estimating the true stratospheric component from the measured $\mathrm{RH}$ values for the cases with enhanced mixing or with insufficient overlap with an intrusion layer. In any case, for the identification of intrusion layers RH thresholds up to $30 \%$ as used in the past (Beekmann et al., 1997; Trickl et al., 2010) will remain adequate. However, due to the mixed composition of the tropopause region some complexity will emerge if one wants to identify ozone of true stratospheric origin.

Alternatively, other tracers could additionally be used for the data filtering. However, the number of substances measured at the Zugspitze summit has been limited and the data not necessarily cover the entire period of the ozone soundings back to 1978. For the future a change in humidity instrumentation and parameters is highly desirable.

Acknowledgements. The authors thank W. Seiler and H. P. Schmid for their interest and support. They also thank H. Smit and H. Vömel for valuable discussions. W. Steinbrecht made available the high-resolution sonde data of the German Weather Service used for the case studies. The development of the water-vapour DIAL and the early measurements with this system were funded by the Bavarian Ministry of Economics and German Federal Ministry of Education and Research within the programme "Atmosphärenforschung 2000" (ATMOFAST, 2005). Also the CO analyses were carried out within ATMOFAST.

The service charges for this open access publication have been covered by a Research Centre of the Helmholtz Association.

Edited by: M. Palm

\section{References}

ATMOFAST: Atmosphärischer Ferntransport und seine Auswirkungen auf die Spurengaskonzentrationen in der freien Troposphäre über Mitteleuropa (Atmospheric Long-range Transport and its Impact on the Trace-gas Composition of the Free Troposphere over Central Europe), Project Final Report, edited by: Kerschgens, M., Stohl, A., and Trickl, T., funded by the German Ministry of Education and Research within the programme "Atmosphärenforschung 2000”, Forschungszentrum Karlsruhe, IMK-IFU (Garmisch-Partenkirchen, Germany), 130 pp., available at: http://www.trickl.de/ATMOFAST.htm (last access: 4 June 2014), with revised publication list (2012), 2005 (in German).

Beekmann, M., Ancellet, G., Blonsky, S., De Muer, D., Ebel, A., Elbern, H., Hendricks, J., Kowol, J., Mancier, C., Sladkovic, R., Smit, H. G. J., Speth, P., Trickl, T., and Van Haver, P.: Regional and global tropopause fold occurrence and related ozone flux across the tropopause, J. Atmos. Chem., 28, 29-44, 1997.

Bithell, M., Vaughan, G., and Gray, L. J.: Persistence of stratospheric ozone layers in the troposphere, Atmos. Environ., 34, 2563-2570, 2000.

Brioude, J., Cammas, J.-P., and Cooper, O. R.: Stratospheretroposphere exchange in a summertime extratropical low: analysis, Atmos. Chem. Phys., 6, 2337-2353, doi:10.5194/acp-62337-2006, 2006.

Brioude, J., Cooper, O. R., Trainer, M., Ryerson, T. B., Holloway, J. S., Baynard, T., Peischl, J., Warneke, C., Neuman, J. A., De Gouw, J., Stohl, A., Eckhardt, S., Frost, G. J., McKeen, S. A., Hsie, E.-Y., Fehsenfeld, F. C., and Nédélec, P.: Mixing between a stratospheric intrusion and a biomass burning plume, Atmos. Chem. Phys., 7, 4229-4235, doi:10.5194/acp-7-4229-2007, 2007.

Brioude, J., Cammas, J.-P., Cooper, O. R., and Nédélec, P.: Characterization of the composition, structure, and seasonal variation of the mixing layer above the extratropical tropopause as revealed by MOZAIC measurements, J. Geophys. Res., 113, D00B01, doi:10.1029/2007JD009184, 2008.

Browell, E. V., Danielsen, E. F., Ismail, S., Gregory, G. L., and Beck, S. M.: Tropopause fold structure determined from airborne lidar and in situ measurements, J. Geophys. Res., 92, 2112-2120, 1987.

Browell, E. V., Fenn, M. A., Butler, C. F., Grant, W. B., Merrill, J. T., Newell, R. E., Bradshaw, J. D., Sandholm, S. T., Anderson, B. E., Bandy, A. R., Bachmeier, A. S., Blake, D. R., Davis, D. D., Gregory, G. L., Heikes, B. G., Kondo, Y., Liu, S. C., Rowland, F. S., Sachse, G. W., Singh, H. B., Talbot, R. W., and Thornton, D. C.: Large-scale air mass characteristics observed over the Western Pacific during summertime, J. Geophys. Res., 111, 1691-1712, 1996.

Browell, E. V., Fenn, M. A., Butler, C. F., Butler, C. F., Grant, W. B., Ismail, S., Ferrare, R. A., Kooi, S. A., Brackett, V. G., Clayton, M. B., Avery, M. A., Barrick, J. D. W., Fuelberg, H. E., Maloney, J. C., Newell, R. E., Zhu, Y., Mahoney, M. J., Anderson, B. E., Blake, D. R., Brune, W. H., Heikes, B. G., Sachse, G. W., Singh, H. B., and Talbot, R. W.: Large-scale air mass characteristics observed over the remote tropical Pacific Ocean during March-April 1999: results from PEM-Tropics B field experiment, J. Geophys. Res., 106, 32481-32501, 2001. 
Carnuth, W. and Trickl, T.: Transport studies with the IFU threewavelength aerosol lidar during the VOTALP Mesolcina experiment, Atmos. Environ., 34, 1425-1434, 2000.

Carnuth, W., Kempfer, U., and Trickl, T.: Highlights of the tropospheric lidar studies at IFU within the TOR Project, Tellus B, 54, 163-185, 2002

Cooper, O., Forster, C., Parrish, D., Dunlea, E., Hübler, G., Fehsenfeld, F., Holloway, J., Oltmans, S., Johnson, B., Wimmers, A., and Horowitz, L.: On the life cycle of a stratospheric intrusion and its dispersion into polluted warm conveyor belts, J. Geophys. Res., 109, D23S09, doi:10.1029/2003JD004006, 2004a.

Cooper, O. R., Forster, C., Parrish, D., Trainer, M., Dunlea, E., Ryerson, T., Hübler, G., Fehsenfeld, F., Nicks, D., Holloway, J., de Gouw, J., Warneke, C., Roberts, J. M., Flocke, F., and Moody, J.: A case study of transpacific warm conveyor belt transport: influence of merging airstreams on trace gas import to North America, J. Geophys. Res., 109, D23S08, doi:10.1029/2003JD003624, 2004b.

Cooper, O. R., Stohl, A., Hübler, G., Hsie, E. Y., Parrish, D. D., Tuck, A. F., Kiladis, G. N., Oltmans, S. J., Johnson, B. J., Shapiro, M., Moody, J. L., and Lefohn, A. S.: Direct transport of midlatitude stratospheric ozone into the lower troposphere and marine boundary layer of the tropical Pacific Ocean, J. Geophys. Res., 100, D23310, doi:10.1029/2005JD005783, 2005.

Danielsen, E. F.: Stratospheric-tropospheric exchange based on radioactivity, ozone and potential vorticity, J. Atmos. Sci., 25, 505518,1968 .

Danielsen, E. F., Hipskind, R. S., Gaines, S. E., Sachse, G. W., Gregory, G. L., and Hill, G. F.: Three-dimensional analysis of potential vorticity associated with tropopause folds and observed variations of ozone and carbon monoxide, J. Geophys. Res., 92, 2103-2111, 1987.

Dee, D. P., Uppala, S. M., Simmons, A. J., Berrisford, P., Poli, P., Kobayashi, S., Andrae, U., Balmaseda, M. A., Balsamo, G., Bauer, P., Bechtold, P., Beljaars, A. C. M., van de Berg, L., Bidlot, J., Bormann, N., Delsol, C., Dragani, R., Fuentes, M., Geer, A. J., Haimberger, L., Healy, S. B., Hersbach, H., Hólm, E. V., Isaksen, L., Kållberg, P., Köhler, M., Matricardi, M., McNally, A. P., Monge-Sanz, B. M., Morcrette, J.-J., Park, B.K., Peubey, C., de Rosnay, P., Tavolato, C., Thépaut, J.-N., and Vitart, F.: The ERA-Interim reanalysis: configuration and performance of the data assimilation system, Q. J. Roy. Meteor. Soc., 137, 553-597, 2011.

Di Girolamo, P., Summa, D., and Ferretti, R.: Multiparameter Raman Lidar measurements for the characterization of a dry stratospheric intrusion event, J. Atmos. Ocean. Tech., 26, 1742-1762, 2009.

Draxler, R. and Hess, G.: An overview of the HYSPLIT_4 modelling system for trajectories, dispersion, and deposition, Aust. Meteorol. Mag., 47, 295-308, 1998.

Eckhardt, S., Stohl, A., Wernli, H., James, P., Forster, C., and Spichtinger, N.: A 15-year climatology of warm conveyor belts, J. Climate, 17, 218-237, 2004.

Eisele, H. and Trickl, T.: Second generation of the IFU stationary tropospheric ozone Lidar, in: Advances in Atmospheric Remote Sensing with Lidar, Selected Papers of the 18th International Laser Radar Conference, Berlin (Germany), 22 to 26 July 1996, edited by: Ansmann, A., Neuber, R., Rairoux, P., and Wandinger, U., Springer, Berlin, Heidelberg, Germany, 379382, 1997.

Eisele, H. and Trickl, T.: Improvements of the aerosol algorithm in ozone-lidar data processing by use of evolutionary strategies, Appl. Optics, 44, 2638-2651, 2005.

Eisele, H., Scheel, H. E., Sladkovic, R., and Trickl, T.: Highresolution Lidar measurements of stratosphere-troposphere exchange, J. Atmos. Sci., 56, 319-330, 1999.

Elbern, H., Kowol, J., Sladkovic, R., and Ebel, A.: Deep stratospheric intrusions: a statistical assessment with model guided analysis, Atmos. Environ., 31, 3207-3226, 1997.

Fischer, H., Wienhold, F. G., Hoor, P., Bujok, O., Schiller, C., Siegmund, P., Ambaum, M., Scheeren, H. A., and Lelieveld, J.: Tracer correlations in the northern latitude lowermost stratosphere: influence of cross-tropopause mass exchange, Geophys. Res. Lett., 27, 97-100, 2000.

Flentje, H., Dörnbrack, A., Ehret, G., Fix, A., Kiemle, C., Poberaj, G., and Wirth, M.: Water vapor heterogeneity related to tropopause folds over the North Atlantic revealed by airborne water vapor differential absorption lidar, J. Geophys. Res., 110, D03115, doi:10.1029/2004JD004957, 2005.

Gettelman, A., Hoor, P., Pan, L. L., Randel, W. L., Hegglin, M. I., and Birner, T.: The extratropical upper troposphere and lower stratosphere, Rev. Geophys., 49, RG3003, doi:10.1029/2011RG000355, 2011.

Hegglin, M. I., Boone, C. D., Manney, G. L., and Walker, K. A.: A global view of the extratropical tropopause transition layer from Atmospheric Chemistry Experiment Fourier Transform Spectrometer $\mathrm{O}_{3}, \mathrm{H}_{2} \mathrm{O}$, and CO, J. Geophys. Res., 114, D00B11, doi:10.1029/2008JD009984, 2009.

Hintsa, E. J., Boering, K. A., Weinstock, E. M., Anderson, J. G., Gary, B. L., Pfister, L., Daube, B. C., Wofsy, S. C., Loewenstein, M., Podolske, J. R., Margitan, J. J., and Bui, T. P.: Troposphere-to-stratosphere transport in the lowermost stratosphere from measurements of $\mathrm{H}_{2} \mathrm{O}, \mathrm{CO}_{2}, \mathrm{~N}_{2} \mathrm{O}$ and $\mathrm{O}_{3}$, Geophys. Res. Lett., 25, 2655-2658, 1998.

Hoerling, M. P., Schaack, T. K., and Lenzen, A. J.: Global objective tropopause analysis, Mon. Weather Rev., 119, 1816-1831, 1991.

Homeyer, C. R., Bowman, K. P., Pan, L. L., Zondlo, M. A., and Bresch, J. F.: Convective injection into stratospheric intrusions, J. Geophys. Res., 116, D23304, doi:10.1029/2011JD016724, 2011.

Hoor, P., Fischer, H., Lange, L., Lelieveld, J., and Brunner, D.: Seasonal variations of a mixing layer in the lowermost stratosphere as identified by the $\mathrm{CO}-\mathrm{O}_{3}$ correlation from in situ measurements, J. Geophys. Res., 107, 4044, doi:10.1029/2000JD000289, 2002.

Hoor, P., Gurk, C., Brunner, D., Hegglin, M. I., Wernli, H., and Fischer, H.: Seasonality and extent of extratropical TST derived from in-situ CO measurements during SPURT, Atmos. Chem. Phys., 4, 1427-1442, doi:10.5194/acp-4-1427-2004, 2004.

Huntrieser, H., Heland, J., Schlager, H., Forster, C., Stohl, A., Aufmhoff, H., Arnold, F., Scheel, H. E., Campana, M., Gilge, S., Eixmann, R., and Cooper, O.: Intercontinental air pollution transport from North America to Europe: experimental evidence from aircraft measurements and surface observations, J. Geophys. Res., 110, D01305, doi:10.1029/2004JD005045, 2005.

Jäger, H.: Long-term record of lidar observations of the stratospheric aerosol layer at Garmisch-Partenkirchen, J. Geophys. Res., 110, D08106, doi:10.1029/2004JD005506, 2005. 
Jonson, J. E., Simpson, D., Fagerli, H., and Solberg, S.: Can we explain the trends in European ozone levels?, Atmos. Chem. Phys., 6, 51-66, doi:10.5194/acp-6-51-2006, 2006.

Kempfer, U., Carnuth, W., Lotz, R., and Trickl, T.: A wide-range UV Lidar system for tropospheric ozone measurements: development and application, Rev. Sci. Instrum., 65, 3145-3164, 1994.

Kuang, S., Newchurch, M. J., Burris, J., Wang, L., Knupp, K., and Huang, G.: Stratosphere-to-troposphere transport revealed by ground-based lidar and ozonesonde at a midlatitude site, J. Geophys. Res., 117, D18305, doi:10.1029/2012JD017695, 2012.

Langford, A. O., Masters, C. D., Proffitt, M. H., Hsie, E. Y., and Tuck, A. F.: Ozone measurements in a tropopause fold associated with a cut-off low system, Geophys. Res. Lett., 23, 2501-2504, 1996.

Lelieveld, J., Bregman, B., Arnold, F., Bürger, V., Crutzen, P. J., Fischer, H., Waibel, A., Siegmund, P., and van Velthoven, P. F. J.: Chemical perturbation of the lowermost stratosphere through exchange with the troposphere, Geophys. Res. Lett., 24, 603-606, 1997.

Logan, J. A., Staehelin, J., Megretskaia, I. A., Cammas, J.P., Thouret, V., Claude, H., De Backer, H., Steinbacher, M., Scheel, H.-E., Stübi, R., Fröhlich, M., and Derwent, R.: Changes in ozone over Europe: analysis of ozone measurements from sondes, regular aircraft (MOZAIC) and alpine surface sites, J. Geophys. Res., 117, D09301, doi:10.1029/2011JD016952, 2012.

Olivier, J. G. J. and Berdowski, J. J. M.: Global emissions sources and sinks in: The Climate System, edited by: Berdowski, J., Guicherit, R., and Heij, B. J., A. A. Balkema Publishers/Swets \& Zeitlinger Publishers, Lisse, the Netherlands, 33-78, 2001.

Oltmans, S. J., Lefohn, A. S., Harris, J. M., Galbally, I., Scheel, H. E., Bodeker, G., Brunke, E., Claude, H., Tarasick, D., Johnson, B. J., Simmonds, P., Shadwick, D., Anlauf, K., Hayden, K., Schmidlin, F., Fujimoto, F., Akagi, K., Meyer, C., Nichol, S., Davies, J., Redondas, A., and Cuevas, E.: Long-term changes in tropospheric ozone, Atmos. Environ., 40, 3156-3173, 2006.

Oltmans, S. J., Lefohn, A. S., Shadwick, D., Harris, J. M., Scheel, H. E., Galbally, I., Tarasick, D. W., Johnson, B. J., Brunke, E.-G., Claude, H., Zeng, G., Nichol, S., Schmidlin, F., Davies, J., Cuevas, E., Redondas, A., Naoe, H., Nakano, T., and Kawasato, T.: Recent tropospheric ozone changes - a pattern dominated by slow or no growth, Atmos. Environ., 67, 331-351, 2012.

Ordoñez, C., Brunner, D., Staehelin, J., Hadjinicolaou, P., Pyle, J. A., Jonas, M., Wernli, H., and Prévôt, A. S. H.: Strong influence of lowermost stratospheric ozone on lower tropospheric background ozone changes over Europe, Geophys. Res. Lett., 34, L07805, doi:10.1029/2006GL029113, 2007.

Pan, L. L., Randel, W. J., Gary, B. L., Mahoney, M. J., and Hintsa, E. J.: Definitions and sharpness of the extratropical tropopause: a trace gas perspective, J. Geophys. Res., 109, D23103, doi:10.1029/2004JD004982, 2004.

Pan, L. L., Bowman, K. P., Shapiro, M., Randel, W. J., Gao, R. S., Campos, T., Davis, C., Schauffler, S., Ridley, B. A., Wei, J. C., and Barnet, C.: Chemical behavior of the tropopause observed during the Stratosphere-Troposphere Analyses of Regional Transport experiment, J. Geophys. Res., 112, D18110, doi:10.1029/2007JD008645, 2007.
Parrish, D. D., Holloway, J. S., Jakoubek, R., Trainer, M., Ryerson, T. B., Hübler, G., Fehsenfeld, F. C., Moody, J. L., and Cooper, O. C.: Mixing of anthropogenic pollution with stratospheric ozone: a case study from the North Atlantic wintertime troposphere, J. Geophys. Res., 105, 24363-24374, 2000.

Parrish, D. D., Law, K. S., Staehelin, J., Derwent, R., Cooper, O. R., Tanimoto, H., Volz-Thomas, A., Gilge, S., Scheel, H.-E., Steinbacher, M., and Chan, E.: Long-term changes in lower tropospheric baseline ozone concentrations at northern mid-latitudes, Atmos. Chem. Phys., 12, 11485-11504, doi:10.5194/acp-1211485-2012, 2012.

Pisso, I., Real, E., Law, K. S., Legras, B., Bousserez, N., Attié, J. L., and Schlager, H.: Estimation of mixing in the troposphere from Lagrangian trace gas reconstructions during longrange pollution-plume transport, J. Geophys. Res., 114, D19301, doi:10.1029/2008JD011289, 2009.

Rastigejev, Y., Park, R., Brenner, M., and Jacob, D.: Resolving intercontinental pollution plumes in global models of atmospheric transport, J. Geophys. Res., 115, D02302, doi:10.1029/2009JD012568, 2010.

Reiter, R., Sládković, K., Pötzl, R., Carnuth, W., and Kanter, H.J.: Measurements of Airborne Radioactivity and its Meteorological Application, series of annual reports, vol. I-VIII (19701977), Physikalisch-Bioklimatische Forschungsstelle (later: Institut für Atmosphärische Umweltforschung) der FraunhoferGesellschaft, Garmisch-Partenkirchen, Germany, prepared for the US Atomic Energy Commission, Division of Biology and Medicine, under Contract AT (30-1)-4061, vol. I: AEC Document Number NYO-4061-2, 1970.

Reiter, R., Sladkovic, R., and Kanter, H.-J.: Concentration of trace gases in the lower troposphere, simultaneously recorded at neighboring mountain stations, Part II: Ozone, Meteorol. Atmos. Phys., 37, 27-47, 1987.

Richter, A., Burrows, J. P., Nüß, H., Granier, C., and Niemeier, U.: Increase in nitrogen dioxide over China observed from space, Nature, 437, 129-132, 2005.

Roelofs, G.-J. and Lelieveld, J.: Model study of the influence of cross-tropopause $\mathrm{O}_{3}$ transports on tropospheric $\mathrm{O}_{3}$ levels, Tellus B, 49, 38-55, 1997.

Roelofs, G. J. Kentarchos, A. S., Trickl, T., Stohl, A., Collins, W. J., Crowther, R. A., Hauglustaine, D., Klonecki, A., Law, K. S., Lawrence, M. G., von Kuhlmann, R., and van Weele, M.: Intercomparison of tropospheric ozone models: ozone transport in a complex tropopause folding event, J. Geophys. Res., 108, 8529, doi:10.1029/2003JD003462, 2003.

Roiger, A., Schlager, H., Schäfler, A., Huntrieser, H., Scheibe, M., Aufmhoff, H., Cooper, O. R., Sodemann, H., Stohl, A., Burkhart, J., Lazzara, M., Schiller, C., Law, K. S., and Arnold, F.: Insitu observation of Asian pollution transported into the Arctic lowermost stratosphere, Atmos. Chem. Phys., 11, 10975-10994, doi:10.5194/acp-11-10975-2011, 2011.

Scheel, H. E., Areskoug, H., Geiß, H., Gomiscek, B., Granby, K., Haszpra, L., Klasinc, L., Kley, D., Laurila, T., Lindskog, A., Roemer, M., Schmitt, R., Simmonds, P., Solberg, S., and Toupance, G.: On the spatial distribution and seasonal variation of lower-tropospheric ozone over Europe, J. Atmos. Chem., 28, 11-28, 1997.

Scheel, H. E.: Report on measurements of $\mathrm{O}_{3},{ }^{7} \mathrm{Be}, \mathrm{RH}$ and $\mathrm{CO}$ at the Zugspitze summit, in: STACCATO - Influence of 
Stratosphere-Troposphere Exchange in a Changing Climate on Atmospheric Transport and Oxidation Capacity, edited by: Stohl, A., Final Report, European Union, Contract EVK2CT-1999-00050, available at: http://www.forst.tu-muenchen.de/ EXT/LST/METEO/staccato/ (last access: 4 June 2014), Technische Universität München (Freising, Germany), 58-62, 2002.

Scheel, H. E.: Ozone climatology studies for the Zugspitze and neighbouring sites in the German Alps, in: Tropospheric Ozone Research 2, EUROTRAC-2 Subproject Final Report, edited by: Lindskog, A., EUROTRAC International Scientific Secretariat (München, Germany, 2003), available at: http://www.trickl.de/ scheel.pdf (last access: 17 September 2014), 134-139, 2003.

Scherer, M., Vömel, H., Fueglistaler, S., Oltmans, S. J., and Staehelin, J.: Trends and variability of midlatitude stratospheric water vapour deduced from the re-evaluated Boulder balloon series and HALOE, Atmos. Chem. Phys., 8, 1391-1402, doi:10.5194/acp8-1391-2008, 2008.

Seibert, P., Feldmann, H., Neininger, B., Bäumle, M., and Trickl, T.: South foehn and ozone in the Eastern Alps - case study and climatological aspect, Atmos. Environ., 34, 1379-1394, 2000.

Shapiro, M. A.: The role of turbulent heat flux in the generation of potential vorticity of upper-level jet stream systems, Mon. Weather Rev., 104, 892-906, 1976.

Shapiro, M. A.: Further evidence of the mesoscale and turbulent structure of upper level jet stream-frontal zone systems, Mon. Weather Rev., 106, 1100-1111, 1978.

Shapiro, M. A.: Turbulent mixing within tropopause folds as a mechanism for the exchange of chemical constituents between the stratosphere and troposphere, J. Atmos. Sci., 37, 994-1004, 1980.

Sladkovic, R. and Munzert, K.: Lufthygienisch-klimatologische Überwachung im bayrischen Alpenraum, Abschnitt V I.4, Ozonspitzen auf der Zugspitze durch Zustrom aus der Stratosphäre, Final Report, Fraunhofer-Institut für Atmosphärische Umweltforschung, Report 908080, Garmisch-Partenkirchen, Germany, 49-50, 1990.

Sprenger, M., Croci Maspoli, M., and Wernli, H.: Tropopause folds and cross-tropopause exchange: a global investigation based upon ECMWF analyses for the time period March 2000 to February 2001, J. Geophys. Res., 108, 8518, doi:10.1029/2002JD002587, 2003.

Sprung, D. and Zahn, A.: Acetone in the upper troposphere/lowermost stratosphere measured by the CARIBIC passenger aircraft: distribution, seasonal cycle, and variability, J. Geophys. Res., 115, D16301, doi:10.1029/2009JD012099, 2010.

Steinbrecht, W., Claude, H., Schönenborn, F., Leiterer, U., Dier, H., and Lanzinger, E.: Pressure and temperature differences between Vaisala RS80 and RS92 radiosonde systems, J. Atmos. Ocean. Tech., 25, 909-927, 2008.

Stohl, A.: A 1-year Lagrangian "climatology" of airstreams in the Northern Hemisphere troposphere and lowermost stratosphere, J. Geophys. Res., 106, 7263-7279, 2001.

Stohl, A. and Trickl, T.: A textbook example of long-range transport: simultaneous observation of ozone maxima of stratospheric and North American origin in the free troposphere over Europe, J. Geophys. Res., 104, 30445-30462, 1999.

Stohl, A., Hittenberger, M., and Wotawa, G.: Validation of the Lagrangian particle dispersion model FLEXPART against large scale tracer experiments, Atmos. Environ., 32, 4245-4264, 1998.
Stohl, A., Spichtinger-Rakowsky, N., Bonasoni, P., Feldmann, H., Memmesheimer, M., Scheel, H. E., Trickl, T., Hübener, S., Ringer, W., and Mandl, M.: The influence of stratospheric intrusions on alpine ozone concentrations, Atmos. Environ., 34, 1323-1354, 2000.

Stohl, A., Eckhardt, S., Forster, C., James, P., Spichtinger, N., and Seibert, P.: A replacement for simple back trajectory calculations in the interpretation of atmospheric trace substance measurements, Atmos. Environ., 36, 4635-4648, $2002 \mathrm{a}$.

Stohl, A., Eckhardt, S., Forster, C., James, P., and Spichtinger, N.: On the pathways and timescales of intercontinental air pollution transport, J. Geophys. Res., 107, 4684, doi:10.1029/2001JD001396, 2002b.

Stohl, A., Eckhardt, S., Spichtinger, N., Huntrieser, H., Heland, J., Schlager, H., Wilhelm, S., Arnold, F., and Cooper, O.: A backward modelling study of intercontinental transport using aircraft measurements, J. Geophys. Res., 108, 4370, doi:10.1029/2002JD002862, 2003a.

Stohl, A., Bonasoni, P., Cristofanelli, P., Collins, W., Feichter, J., Frank, A., Forster, C., Gerasopoulos, E., Gäggeler, H., James, P., Kentarchos, T., Kromp-Kolb, H., Krüger, B., Land, C., Meloen, J., Papayannis, A., Priller, A., Seibert, P., Sprenger, M., Roelofs, G. J., Scheel, H. E., Schnabel, C., Siegmund, P., Tobler, L., Trickl, T., Wernli, H., Wirth, V., Zanis, P., and Zerefos, C.: Stratosphere-troposphere exchange - a review, and what we have learned from STACCATO, J. Geophys. Res., 108, 8516, doi:10.1029/2002JD002490, 2003b.

Stohl, A., Wernli, H., James, P., Bourqui, M., Forster, C., Liniger, M. A., Seibert, P., and Sprenger, M.: A new perspective of stratosphere-troposphere exchange, B. Am. Meteorol. Soc., 84, 1565-1573, 2003c.

Stohl, A., Cooper, O. R., and James, P.: A cautionary note on the use of meteorological analysis fields for quantifying atmospheric mixing, J. Atmos. Sci., 61, 1446-1453, 2004.

Stohl, A., Forster, C., Frank, A., Seibert, P., and Wotawa, G.: Technical note: The Lagrangian particle dispersion model FLEXPART version 6.2, Atmos. Chem. Phys., 5, 2461-2474, doi:10.5194/acp-5-2461-2005, 2005.

Stohl, A., Forster, C., Huntrieser, H., Mannstein, H., McMillan, W. W., Petzold, A., Schlager, H., and Weinzierl, B.: Aircraft measurements over Europe of an air pollution plume from Southeast Asia - aerosol and chemical characterization, Atmos. Chem. Phys., 7, 913-937, doi:10.5194/acp-7-913-2007, 2007.

Trickl, T., Cooper, O. C., Eisele, H., James, P., Mücke, R., and Stohl, A.: Intercontinental transport and its influence on the ozone concentrations over central Europe: three case studies, J. Geophys. Res., 108, 8530, doi:10.1029/2002JD002735, 2003.

Trickl, T., Feldmann, H., Kanter, H.-J., Scheel, H.-E., Sprenger, M., Stohl, A., and Wernli, H.: Forecasted deep stratospheric intrusions over Central Europe: case studies and climatologies, Atmos. Chem. Phys., 10, 499-524, doi:10.5194/acp-10-499-2010, 2010.

Trickl, T., Bärtsch-Ritter, N., Eisele, H., Furger, M., Mücke, R., Sprenger, M., and Stohl, A.: High-ozone layers in the middle and upper troposphere above Central Europe: potential import from the stratosphere along the subtropical jet stream, Atmos. Chem. Phys., 11, 9343-9366, doi:10.5194/acp-11-9343-2011, 2011.

Trickl, T., Giehl, H., Jäger, H., and Vogelmann, H.: 35 yr of stratospheric aerosol measurements at Garmisch-Partenkirchen: from 
Fuego to Eyjafjallajökull, and beyond, Atmos. Chem. Phys., 13, 5205-5225, doi:10.5194/acp-13-5205-2013, 2013.

Vautard, R., Szopa, S., Beekmann, M., Menut, L., Hauglustaine, D. A., Rouil, L., and Roemer, M.: Are decadal anthropogenic emission reductions in Europe consistent with surface ozone observations?, Geophys. Res. Lett., 33, L13810, doi:10.1029/2006GL026080, 2006.

Vogel, B., Pan, L. L., Konopka, P., Günther, G., Müller, R., Hall, W., Campos, T., Pollack, I., Weinheimer, A., Wei, J., Atlas, E. L., and Bowman, K. P.: Transport Pathways and signatures of mixing in the extratropical tropopause region derived from Lagrangian model simulations, J. Geophys. Res., 116, D05306, doi:10.1029/2010JD014876, 2011.

Vogelmann, H. and Trickl, T.: Wide-range sounding of freetropospheric water vapor with a Differential-Absorption Lidar (DIAL) at a high-altitude station, Appl. Optics, 47, 2116-2132, 2008.

Vogelmann, H., Sussmann, R., Trickl, T., and Borsdorff, T.: Intercomparison of atmospheric water vapor soundings from the differential absorption lidar (DIAL) and the solar FTIR system on Mt. Zugspitze, Atmos. Meas. Tech., 4, 835-841, doi:10.5194/amt-4-835-2011, 2011.

Volz, A. and Kley, D.: Evaluation of the Montsouris series of ozone measurements made in the nineteenth century, Nature, 332, 240 242,1988

Wernli, H.: A Lagrangian-based analysis of extratropical cyclones. II: A detailed case study, Q. J. Roy. Meteor. Soc., 123, 16771706, 1997.

Wernli, H. and Davies, H. C.: A Lagrangian-based analysis of extratropical cyclones. I. The method and some applications, Q. J. Roy. Meteor. Soc., 123, 467-489, 1997.
Wirth, M., Fix, A., Ehret, G., Reichardt, J., Begie, R., Engelbart, D., Vömel, H., Calpini, B., Romanens, G., Apituley, A., Wilson, K. M, Vogelmann, H., and Trickl, T.: Intercomparison of airborne water vapour DIAL measurements with ground based remote sensing and radiosondes within the framework of LUAMI 2008, Contribution S07-P01-1 (3 pp.), in: Proceedings of the 8th International Symposium on Tropospheric Profiling (ISTP2009), Delft (the Netherlands), 19 to 23 October 2009, edited by: Apituley, A., Russchenberg, H. W. J., and Monna, W. A. A., RIVM, Bilthoven, the Netherlands, available at: http://www.knmi.nl/ apituley/files/istp8/ (last access: 5 June 2014), 2009.

WMO: Atmospheric Ozone 1985 Assessment of our Understanding of the Processes Controlling its Present Distribution and Change, Report No. 16, Vol. I, World Meteorological Organization, Geneva (Switzerland), 264 pp., 1986.

Zahn, A. and Brenninkmeijer, C. A. M.: New directions: a chemical tropopause defined, Atmos. Environ., 37, 439-440, 2003.

Zahn, A., Neubert, R., Maiss, M., and Platt, U.: Fate of long-lived trace species near the Northern Hemisphere tropopause: carbon dioxide, methane, ozone, and sulfur hexafluoride, J. Geophys Res., 104, 13923-13942, 1999.

Zanis, P., Trickl, T., Stohl, A., Wernli, H., Cooper, O., Zerefos, C., Gaeggeler, H., Schnabel, C., Tobler, L., Kubik, P. W., Priller, A., Scheel, H. E., Kanter, H. J., Cristofanelli, P., Forster, C., James, P., Gerasopoulos, E., Delcloo, A., Papayannis, A., and Claude, H.: Forecast, observation and modelling of a deep stratospheric intrusion event over Europe, Atmos. Chem. Phys., 3, 763-777, doi:10.5194/acp-3-763-2003, 2003. 